\title{
The Alchemy of Effective Auditor Regulation
}

Sarah J. Williams

Penn State Dickinson Law, sjw6018@psu.edu

Follow this and additional works at: https://ideas.dickinsonlaw.psu.edu/fac-works

Part of the Administrative Law Commons, and the Banking and Finance Law Commons

\section{Recommended Citation}

Sarah J. Williams, The Alchemy of Effective Auditor Regulation, 25 Lewis \& Clark. L. Rev. 1089 (2022).

This Article is brought to you for free and open access by the Faculty Scholarship at Dickinson Law IDEAS. It has been accepted for inclusion in Faculty Scholarly Works by an authorized administrator of Dickinson Law IDEAS. For more information, please contactlja10@psu.edu. 


\title{
THE ALCHEMY OF EFFECTIVE AUDITOR REGULATION
}

\author{
by \\ Sarah J. Williams*
}

The audit profession has repeatedly failed in its obligation to accurately opine on financial statements prepared by companies that trade in U.S. markets. The list of entities that have contributed to the quest for effective regulation of these auditors is long; it includes the American Institute of Certified Public Accountants (AICPA), the U.S. Securities and Exchange Commission (SEC), Congress, outside directors of public companies, and the Public Company Accounting Oversight Board (PCAOB), a recent congressional creation. Yet, despite 50 years of effort, the formula for efficacious oversight of the andit profession remains elusive.

In 2020, then-president Donald Trump proposed to subsume the PCAOB into the SEC, citing regulatory duplication and budget savings. This proposal could have been summarily dismissed as fodder for a deregulatory political agenda, but reactions to the proposal from those outside the discrete enclave of securities regulators revealed deeper concerns about the state of auditor regulation that beg our attention.

This Article is the first in a series of planned articles exploring regulation theory as a path to answering the clamant question: What is the alchemy of effective auditor oversight? This Article begins the discussion by examining the methods by which regulators have determined which auditors would be subject to regulatory oversight, and the extent to which that process furthers the purported goals of more reliable audit reports. This Article establishes that regulatory processes to define the audience of regulated entities have been disinterested at best, and self-interested at worst. This Article articulates the need for a complete departure from the stale, recycled approaches that have been implemented under the guise of improved regulation. A fresh approach with a

* Sarah J. Williams is an Assistant Professor of Law at Penn State Dickinson Law with over 25 years of experience as a securities regulator. She served for 15 years as Deputy Director at the Public Company Accounting Oversight Board. She served as Counsel to Commissioner Isaac C. Hunt Jr., Enforcement Division Branch Chief, and Enforcement Division Staff Attorney while at the U.S. Securities and Exchange Commission, and performed the roles of Assistant and Associate General Counsel at NASD (now FINRA). The author thanks her colleagues at Dickinson Law for their support in writing this Article, as well as her research assistant, Najeebah L. Beyah, for her diligence in performing legal research and gathering data vital to the author's scholarly agenda. 
clear nexus to the objective of promoting fair and accurate audits of public company financial statements is imperative to advancing in the discovery of an efficacious formula for auditor oversight.

Introduction 1090

I. The Creation of Auditors as Gatekeepers

II. Discarded Formulas for Auditor Oversight

A. The Audit Profession as Rule Makers.

B. The Outside Directors as Auditor Overseers.....

C. Deputizing the Audit Profession.................................................... 1100

D. Creating a New Regulator. 1106

III. Affixing the Lens of Regulatory Theory ......................................... 1108

A. The Rubric of Regulation ......................................................... 1108

B. The Role of Verifiability in the Auditor Oversight Regime ............... 1110

C. Using Verifiability to Establish Expectations for Auditors ................ 1113

D. Using Verifiability to Establish Expectations for Investors.....

IV. Redesigning the Approach to Regulated Auditors to Produce Effective Oversight

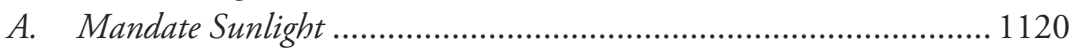

B. Streamline Verifiability....................................................... 1122

C. Strengthen Registration Criteria ................................................... 1123

Conclusion.

Appendix 1: Content of SECPS and PCAOB Applications 1127

\section{INTRODUCTION}

The Public Company Accounting Oversight Board ("PCAOB" or "Board") is a private, governmentally created, nonprofit entity empowered with extensive power to oversee accounting firms involved in auditing public companies pursuant to federal securities law. ${ }^{1}$ Since its inception, the PCAOB's unique creational model has attracted scholarly attention. ${ }^{2}$ Beyond that, the agency has been largely

1 Free Enter. Fund v. PCAOB, 561 U.S. 477, 484-85 (2010).

2 See, e.g., Donna M. Nagy, Playing Peekaboo with Constitutional Law: The PCAOB and Its Public/Private Status, 80 Notre Dame L. Rev. 975, 981 (2005) [hereinafter Nagy, Playing Peekaboo]; Donna M. Nagy, Is the PCAOB a "Heavily Controlled Component" of the SEC?: An Essential Question in the Constitutional Controversy, 71 U. PITT. L. REV. 361 (2010) [hereinafter Nagy, $P C A O B]$ (providing a constitutional analysis of the PCAOB after issuance of a decision in Free Enterprise Fund v. PCAOB, 537 F.3d 667 (D.C. Cir. 2008)); Michael A. Thomason, Jr., Note, Auditing the PCAOB: A Test to the Accountability of the Uniquely Structured Regulator of Accountants, 62 VAND. L. REv. 1953 (2009) (analyzing the applicability of the Appointments Clause to the $\mathrm{PCAOB}$ ). 
consigned to the category of obscurity in academia. ${ }^{3}$ On February 10, 2020, the Office of Management and Budget (“OMB”) released then-President Trump's Budget of the U.S. Government for Fiscal Year 2021, which included a volume entitled The Major Savings and Reforms, Budget of the United States Government, Fiscal Year 2021. ${ }^{4}$ The proposed budget recommended the consolidation of the 18year-old PCAOB into the U.S. Securities and Exchange Commission ("SEC"), starting in 2022..$^{5}$ The justifications for the consolidation were presented as reductions in agency ambiguity and duplication. The proposal further noted that moving the Board's responsibilities to the SEC would ensure oversight over the fees assessed on market participants. ${ }^{6}$

To the extent Trump's proposal to transfer the responsibilities of the PCAOB to its overseer reflects concerns about the conduct of the audit profession, it is far from groundbreaking. The proposal is yet another foray in the decades old struggle to unearth the formula that will turn auditors into effectively regulated entities. The history of regulation of public company auditors reveals a sporadic and reactive rejumbling of corporate, governmental, professional, and non-governmental resources, in a trial-and-error fashion, that has most recently produced the PCAOB. ${ }^{7}$ A plethora of possibilities exist for the allocation of responsibilities among the various parties interested in promoting quality audits of public company financial statements. The entities that may be involved in such oversight range from the accounting associations charged with training and supporting public company auditors, to the public companies in need of audit services, to the government regulators responsible for mandating the use of auditors - in this case, the SEC. The newest entrant in the evolving apportionment of audit oversight responsibility is the PCAOB, a congressionally created, yet non-governmental agency, which currently carries the bulk of the auditor oversight responsibility. ${ }^{8}$

3 See, e.g., Confirmation Hearing on the Nomination of Hon. Brett M. Kavanaugh to be an Associate Justice of the Supreme Court of the United States: Hearing Before the S. Comm. on the Judiciary, 115th Cong. 1072 (2018) (statement of Lisa Heinzerling, Professor of Law, Georgetown University Law Center) (referring to the PCAOB as "rather obscure").

4 Off. of Mgmt. \& Budget, A Budget for America's Future: Major Savings and REFORMS, FISCAL YEAR 2021 (2020).

5 Id. at 179.

${ }^{6}$ Id.; see also Mark Maurer \& Paul Kiernan, White House Proposal for SEC to Absorb Audit Watchdog Raises Concerns, Wall ST. J. (Feb. 13, 2020, 3:05 PM), https://www.wsj.com/ articles/white-house-proposal-for-sec-to-absorb-audit-watchdog-raises-concerns-11581624345 (noting likely savings from combining the two entities as a result of removing duplicative costs in such areas as information technology and administration).

7 Daniel Austin Green, Accounting's Nadir: Failures of Form or Substance?, 12 U. PA. J. BuS. L. 601, 633-34 (2010) ("Every bit of PCAOB's mission and power was already part of the existing, if broken and failing, structure of accounting oversight. Sarbanes-Oxley, in creating PCAOB, in no way remedied any flaws.").

8 Andrew J. Morris, The Sarbanes Oxley Privilege for Public Company Accounting Oversight 
Trump's proposal should have stirred a mainstream debate over the costs and efficacy of the PCAOB as a regulatory body, given the interests of many American households in reliable audits of the financial condition of their investments, as well as the use of money from the companies in which Americans invest to fund the operations of the agency. ${ }^{9}$ Yet, the PCAOB and the statute creating it are largely disregarded by the public, crippling accountability and improvement. ${ }^{10}$ Reactions to the budget proposal by those involved in financial regulation were swift and varied. A supporter of Trump's proposal opined that the PCAOB was an ineffective regulator. ${ }^{11}$ Opponents protested that moving the PCAOB's responsibilities to the

Board Materials: Its Implications for SEC Enforcement Proceedings, 5 HARV. Bus. L. REV. ONLINE 87, 87 (2015) ("Congress created the Public Company Accounting Oversight Board-the 'PCAOB' - and charged it to oversee the auditors of public companies.”).

Esteemed scholars have explored the regulatory classification of the PCAOB, given its confusing status as a congressionally created yet non-governmental entity that is privately funded but overseen by the SEC. See, e.g., William A. Birdthistle \& M. Todd Henderson, Becoming a Fifth Branch, 99 Cornell L. REV. 1, 60 n.279 (2013) (noting the incongruity of delegating regulatory powers to private entities like the $\mathrm{PCAOB}$ without mandating the corresponding transparency and accountability of governmental agencies); Nagy, PCAOB, supra note 2, at 385 (noting that the PCAOB is unlike a self-regulatory organization in that it was created by the government and its leadership is appointed by the government); CATHERINE E. RUDDER, A. LEE Fritschler \& Yon Jung Choi, Public Policymaking By Private Organizations: Challenges to a Democratic Governance 11, 68-69 (2016) (characterizing the PCAOB as a private, hybrid agency created by, yet operating with some degree of independence from, the government). Moreover, the academy has considered the wisdom of cloning this approach to create new regulatory agencies in other areas of securities regulation. See, e.g., Roberta S. Karmel, The Challenge of Fiduciary Regulation: The Investment Advisers Act After Seventy-Five Years, 10 Brook. J. CorP. Fin. \& COM. L. 405, 426-27 (2016) (discussing the Consumer Federation of America's support for an agency modeled after the PCAOB to oversee investment advisers). This Article does not endeavor to replicate or improve upon these bodies of scholarship.

9 See Paul D. Paton, Rethinking the Role of the Auditor: Resolving the Audit/Tax Services Debate, 32 QUEEN's L.J. 135, 158 (2006) (explaining that the PCAOB is funded by investors in public companies in an effort to enhance the agency's independence); see also Christopher C. DeMuth Sr. \& Michael S. Greve, Agency Finance in the Age of Executive Government, 24 GEO. MASON L. REV. 555, 565 (2017) (“The PCAOB's annual budget of about $\$ 250$ million is funded almost entirely by its own tax, which it calls an 'accounting support fee,' on the equity capital or net asset value of public companies and broker-dealers.").

10 Cheryl L. Wade, The Sarbanes-Oxley Act and Ethical Corporate Climates: What the Media Reports; What the General Public Knows, 2 BrooK. J. Corp. FIn. \& COM. L. 421, 422 (2008) ("Only a fragment of the population participates in today's discourse about [the Sarbanes-Oxley Act].... The general public no longer has easy access to (or interest in) news about the Act's shortcomings, or the changes in the way the Act is interpreted or implemented ... If the public is no longer paying attention, the business community no longer needs to concern itself with its public image.").

11 Jim Peterson, So What if the SEC Swallowed the PCAOB?, GOING CONCERN (Apr. 1, 2020), https://www.goingconcern.com/what-if-sec-swallowed-pcaob/?doing_wp_cron=1613243 935.4288289546966552734375 ("Never in its history has the PCAOB punched even its own 
SEC would exceed the government regulator's bandwidth, ${ }^{12}$ and the agency's termination would signal that "high quality audits are no longer a priority." 13 Defenders of the PCAOB supported its continuing existence, but some nonetheless noted concern about its approach and function. ${ }^{14}$ Skeptics of the PCAOB's success in fulfilling its mission of improved audit quality expressed agnosticism at the prospect of the agency's consolidation. ${ }^{15}$ It is also important to note that the PCAOB was the object of criticism before Trump proposed its consolidation. Scholars previously warned that that SEC's delegation of authority to the PCAOB created additional oversight costs, shrouded regulatory activities from public purview, and created regulatory tension with the SEC. ${ }^{16}$ In response to criticisms of

light weight. . . The PCAOB had no visible effect during the 2007-2008 crisis, when cascades of companies with clean audit opinions fell into failure, take-over, or government bail-out. Nor does it inspire confidence that outbreaks of predictably doubtful behavior continue apace-recent examples include Mattel, UnderArmour .....").

12 See, e.g., Arthur Levitt, Without an Independent Watchdog, Who Will Audit the Auditors?, WALL ST. J., Feb. 20, 2020, at A17 ("The [Securities and Exchange] commission's mandate is already full, and to meet the expectations set for the PCAOB would require an expansion of staff and expertise not currently funded by the Trump administration's budget proposal."); Jovalin Dedaj, Trump Plan to Nix Audit Watchdog Would Hurt Markets, Law360 (Mar. 2, 2020, 4:27 PM), https://www.law360.com/articles/1245589/trump-plan-to-nix-audit-watchdogwould-hurt-markets ("The SEC may not have the expertise to take the PCAOB's place and, even though the SEC's total outlays are set to increase through 2025 by $\$ 78$ million, it is unclear how much of that increased funding would be dedicated to audit inspection and enforcement.").

13 James R. Doty, How Congress Got It Right on Audit Oversight, CLS Blue Sky BlOG (Feb. 24, 2020), https://clsbluesky.law.columbia.edu/2020/02/24/how-congress-got-it-right-on-auditoversight/.

14 Levitt, supra note 12, at A17 (concluding that while the PCAOB is a good idea overall, the agency should be more aggressive in its enforcement efforts, and the SEC's supervision of the agency is inadequate); Jason Bramwell, Could We Soon Be Living in a PCAOB-less World?, GOING CONCERN (Feb. 11, 2020), https://www.goingconcern.com/could-we-soon-be-living-in-a-pcaobless-world/ (describing the views of one accounting professor that the PCAOB should leave standard setting to the accounting profession, and a different accounting professor's opinion that the SEC should assume the PCAOB's inspection function only).

15 Peterson, supra note 11 ("For the moment, however, ill-motivated as may be the enthusiasm of this White House to kill off the PCAOB, the 18-year failure to justify its existence makes its proposed disappearance of too little consequence to matter.").

16 Gideon Mark, Accounting Fraud: Pleading Scienter of Auditors Under the PSLRA, 39 CONN. L. ReV. 1097, 1112 (2007) ("Nevertheless, the PCAOB considers itself to be a supervisory-rather than enforcement-body, and to this extent its effectiveness is inherently limited."); Donna M. Nagy, Regulating the Mutual Fund Industry, 1 BRoOK. J. CORP. FIN. \& COM. L. 11, 31 (2006) ("As a private entity, even one that is subject to SEC oversight, the PCAOB is less publicly accountable, its operations are less transparent, and its policymaking is less legitimate than its federal regulatory counterparts. Moreover, the PCAOB's status as a private corporation raises, rather than lowers, the overall costs of its regulatory program."); Green, supra note 7, at 631 ("Since PCAOB's creation, it has been engaged in an extensive turf war with the 
the agency lobbed by former SEC Chairman Arthur Levitt, William Duhnke, then chairman of the PCAOB, apparently affirmed perceptions about the agency's lack of transparency. ${ }^{17}$

This Article is the first in a series that critically examines individual pillars of audit regulation to discern optimal operation from the perspective of improved audit quality and cost effectiveness. With that foundational analysis complete, the culminating article will propose the optimal regulatory approach for effective audits of public companies. ${ }^{18}$

To the extent the PCAOB is a refurbished version of previously discarded and ineffective regulatory approaches, Trump's proposal for its demise has some allure. It, and the insular dialogue it stimulated, begs a larger question: What balance of participation among the various entities impacting audit quality will achieve optimal regulation? Put another way, what is the alchemy of effective auditor oversight? This Article is the first in a series that explores that question through the lens of regulation theory. It examines the history of auditor oversight to discern the elements necessary to optimize regulatory effectiveness of audits of public companies. The series accomplishes this goal using the core PCAOB functions as a baseline for assessing effective regulation.

This foundational contribution to the series is devoted to the structural core of auditor oversight-identifying regulatory recipients. Regulatory theory would categorize this activity as a form of verifiability. ${ }^{19}$ The manner in which audit firms are targeted for regulatory oversight has morphed over the years and currently exists under the PCAOB's approach as audit firm registration. The dearth of scholarship on the PCAOB registration process has been lamented. ${ }^{20}$ Further, the need for close

SEC, and the SEC appears to be winning.").

17 Michael Cohn, PCAOB Plans Further Changes on Inspections and Quality Control, ACCT. TODAY (Dec. 3, 2019, 6:13 PM), https://www.accountingtoday.com/news/pcaob-plans-furtherchanges-on-inspections-and-quality-control (quoting Duhnke, in responding to former SEC Chairman Arthur Levitt's criticisms of the agency, as saying, "The only people who know what's going on at the PCAOB are the people working at the PCAOB, so let me tell you, I disagree with the vast majority of what former Chairman Levitt wrote.").

18 The PCAOB is also responsible for overseeing the audits of broker-dealers, a responsibility it received in 2010 via the Dodd-Frank Wall Street Reform and Consumer Protection Act, in response to the Bernie Madoff scandal. This primordial Article does not address the PCAOB's responsibilities with respect to audits of broker-dealers.

19 Verifiability encompasses a broad category of activities undertaken to facilitate monitoring of regulated groups for purposes of assessing compliance. David L. Markell \& Robert L. Glicksman, A Holistic Look at Agency Enforcement, 93 N.C. L. REV. 1, 18 (2014).

20 John L. Abernathy, Michael Barnes \& Chad Stefaniak, A Summary of 10 Years of PCAOB Research: What Have We Learned?, 32 J. ACCT. Literature 30, 33 (2013) ("Despite the significance of the registration process, there is a paucity of academic literature regarding registration with the PCAOB."). 
examination of the functions performed by non-governmental regulators is dire. ${ }^{21}$ This Article helps to fill that void. The Article expresses the view that improvements to the process by which regulators obtain oversight of audit firms are needed to transform it from a vestige of self-regulation to a tool of audit quality improvement.

Part I of this Article reviews the history of audit regulation and the consequences for investors when audits are performed poorly. Part II describes prior attempts to improve the quality of public company audits. Part III presents the traditional rubric for effective regulation, identifies the oversight functions of audit firm membership and registration as regulatory verifiability, and explores the implications of these functions as previously implemented. Part IV outlines initiatives to reset existing approaches to verifiability, which are mired in irrelevant remnants of self-regulation, to align with improved audit quality. This Article asserts that changes to the auditor registration process are necessary to achieve improvements in the quality of the audits upon which U.S. investors rely, and stem the tide of rising costs of auditor regulation.

\section{THE CREATION OF AUDITORS AS GATEKEEPERS}

The practice of accountancy began in the ancient civilizations of Egypt and Mesopotamia. ${ }^{22}$ The invention of the abacus and transition from Roman numerals to Arabic numbers in the eleventh century improved the usability of accounting, and the documentation of double-entry bookkeeping in the fourteenth century strengthened its accuracy. ${ }^{23}$ While accountants are typically referred to as bean counters, they are actually responsible for ensuring that the bean count is recorded in a manner consistent with applicable accounting principles. ${ }^{24}$

The practice of auditing financial records evolved centuries after the practice of accountancy developed. ${ }^{25}$ The auditor's role was to protect shareholders of the enterprise from the poor recordkeeping practices and wrongful financial acts of the entity's management. ${ }^{26}$ While accountants were responsible for preparing the books and records of an entity, it was the auditor's job to confirm, by reviewing the entries and examining supporting evidence, the accuracy of those records. ${ }^{27}$ Audit

21 RUDDER ET AL., supra note 8, at 152 (“[P] rivate governance needs to be seen. Making it visible is the work of scholars, specialists in think tanks, and the serious press.").

22 Stacey L. BOWERS, ACCOUNTING ANd CORPORATE FinANCE FOR LAWYers 1-2 (2019).

23 Id. at 2.

24 See generally MATTHEW J. BARRETT \& DAVID R. HERWITZ, ACCOUNTING FOR LAWYERS 155 (5th ed. 2015).

251 John L. Carey, Rise of the Accounting Profession, From Technician to Professional, 1896-1936, at 5 (1969) (describing the advent of independent auditors in the mid-19th century).

26 Id.

27 Id. at 17 (describing the role of auditors under English law in 1845 as affirming or 
standards, training requirements, and professional associations emerged around this newly forged position. English accountancy practices then migrated to the United States. ${ }^{28}$ British accountants appeared in the United States, reviewing American companies' financial statements for their English clients, and establishing accounting firms in the country. This influx fueled the growth of American accountancy firms, and encouraged the formation of professional accounting organizations, including the American Association of Public Accountants (now the American Institute of Certified Public Accountants or "AICPA") in $1887 .{ }^{29}$

While the practice of accountancy grew in the United States, English law requiring independent audits did not take root in America as quickly. American bankers encouraged independent audits, but no law made it mandatory. ${ }^{30}$ Accounting became more complex after anti-trust legislation encouraged the merger of industry competitors. A premier example of the challenges of such mergers is the 1901 consolidation of eight competing steel companies to form the largest corporation then in existence, United States Steel Corporation ("U.S. Steel"). The creation of U.S. Steel brought a widely diverse group of investors together in one enterprise, ${ }^{31}$ and raised challenging questions about how to present the financial information of the new entity. The company's shareholders elected Price Waterhouse \& Co. as its auditor, which insisted that the financial statements reflect a consolidation of the financial information of each of the operating subsidiaries of U.S. Steel, not the financial position of the parent company alone. ${ }^{32}$ This evolution in the disclosure of financial information elevated the importance of both accounting and auditing in the United States.

The complexities of corporate structures inspired the American accounting industry to value accurate disclosures regarding financial conditions to shareholders, and independent audits of such financial information to ensure the reliability of those disclosures. ${ }^{33}$ Some companies took the initiative to obtain financial statement

reporting on the financial accounts presented by corporate management).

28 Id. at 21-22.

29 History of Accounting: An InTERnational EnCyClopedia 156 (Michael Chatfield \& Richard Vangermeersch eds., 1996).

30 Sean M. O'Connor, Be Careful What You Wish For: How Accountants and Congress Created the Problem of Auditor Independence, 45 B.C. L. REv. 741, 750-51 (2004) (explaining that while provisions for auditors began to appear in English Law in the 1840's, auditor protections in United States appeared much later).

31 John C. Coffee, Jr., The Rise of Dispersed Ownership: The Roles of Law and the State in the Separation of Ownership and Control, 111 YALE L.J. 1, 33 (2001) ("[T] he Sherman Act triggered a wave of horizontal mergers among competitors that, in the process, also diluted existing blockholders and thereby created dispersed ownership.").

32 History of ACCOUNTING, supra note 29, at 601.

33 Am. Inst. of Accountants, Examination of Financial Statements by IndEPENDENT PUblic ACCOUNTANTS 1 (1936) (explaining that complexities in business 
audits. For example, a large insurance company located in New York hired the firms of Price Waterhouse \& Co. and Haskins \& Sells to conduct audits of their financial statements in 1905, after facing investigation by the New York state legislature based on allegations of excessive spending and speculative investments. ${ }^{34}$ While the number of companies receiving voluntary audits of their financial information rose, the practice of using outside auditors as a shareholder protection mechanism remained optional in the United States for a number of years. The New York Stock Exchange ("NYSE") was instrumental in generating change in this area.

The NYSE fashioned itself as an elite market, trading only the highest quality of stocks at high volumes and high prices. ${ }^{35}$ Consistent with this approach, and on the heels of the stock market crash of 1929, the NYSE established a rule in 1932 that required all newly listed companies to receive independent audit reports on their financial condition. ${ }^{36}$ This mandate (along with certain other investor protection rules) became federal law with the enactment of the Securities Exchange Act of $1934 .{ }^{37}$ Thus, audits of financial statements became mandatory in the United States for publicly traded companies as a tool of investor protection, and continues to serve that function today.

\section{DISCARDED FORMULAS FOR AUDITOR OVERSIGHT}

\section{A. The Audit Profession as Rule Makers}

Independent audits, while valuable, proved fallible in identifying unreliable financial statements of public companies. ${ }^{38}$ The first significant example of this fallibility after the adoption of mandatory audit reports for public companies trading in the United States involved an accounting fraud at McKesson \& Robbins, Inc. ${ }^{39}$

organizations and industrial progress made it more challenging for businessmen to value their assets).

34 CAREY, supra note 25, at 29-30 (describing the launch of an investigation by the State of New York after public allegations of internal difficulties at large insurance companies); see also Lissa L. Broome \& Jerry W. Markham, Banking and Insurance: Before and After the Gramm-LeachBliley Act, 25 IOwA J. CORP. L. 723, 730 (2000) (describing the allegations that led to New York's investigation of insurance companies).

35 Coffee, supra note 31, at 36.

36 Sean M. O'Connor, Strengthening Auditor Independence: Reestablishing Audits as Control and Premium Signaling Mechanisms, 81 WASH. L. REV. 525, 538 (2006).

37 Id. at 529.

38 Douglas C. Michael, Self-Regulation for Safety and Security: Final Minutes or Finest Hour?, 36 Seton Hall L. Rev. 1075, 1098 (2006) (noting that while the Enron crisis, which led to the creation of the PCAOB, was new, detection of issues in the accounting performed by U.S. public companies was a familiar occurrence).

39 Sheila D. Foster \& Bruce A. Strauch, Auditing Cases That Made a Difference: McKesson \& Robbins, 5 J. BUS. CASE STUD., July/August 2009, at 1, 1 (declaring McKesson \& Robbins one of 
An SEC report of findings on the company revealed that after 13 years of operation under the leadership of its President Frank Coster, the company's financial statements reflected fictitious sales transactions with non-existent entities that generated almost $\$ 2$ million in paper profits and approximately $\$ 21$ million in imaginary assets. ${ }^{40}$ The report also revealed the Frank Coster was an alias adopted by Philip Musica, a convicted fraudster. ${ }^{41}$

Price, Waterhouse \& Co. ("Price Waterhouse") had served as the outside auditor for McKesson, but its audits of the company's financial statements failed to detect the phony transactions on the company's books. Musica was able to carry out this accounting fraud under the noses of the Price Waterhouse accountants by focusing the phony transactions in an area he knew the auditors did not physically check-inventory. ${ }^{42}$ Inventory, at that time, was reviewed using paper records, not by physical confirmation. ${ }^{43}$ Musica's fraud was ultimately uncovered by company insiders who had been stonewalled in their plan to convert the company's profits into cash. ${ }^{44}$

The SEC investigation into this matter concluded that Price Waterhouse had committed no wrongdoing, as its reliance on records to confirm inventory was consistent with generally accepted auditing practices in effect at that time, but noted a substantial body of "equally authoritative opinion" supporting the view that auditors should make physical contact with inventory as part of their processes. ${ }^{45}$ The need for formal standards to govern the audit process was glaring; the question presented was to whom the responsibility for creating those standards should fall. The SEC answered this question in 1941, when it introduced the notion of generally accepted audit standards into the auditor's opinion, thereby bestowing upon the accounting profession the obligation to create formal audit standards. ${ }^{46}$ The accounting profession answered that call by establishing a Committee on Auditing Procedures to develop a set of audit standards, including steps requiring physical contact with inventory during an audit. ${ }^{47}$ This development represented the formal

the earliest cases vital to the development of audit standards).

40 McKesson \& Robbins, Inc., Exchange Act Release No. 2707, 1940 SEC LEXIS 1528, at *5 (Dec. 5, 1940).

41 Id.

42 Charles Keats, Magnificent Masquerade 71-72 (Richard P. Brief ed., 1982).

43 Id.

44 Jaysinha S. Shinde, John Willems, Menghistu M. Sallehu \& Matthew P. Merkle, Establishment of GAAS: Impact of an Auditing Fraud, 15 J. ACCT. \& FIN. 40, 42 (2015).

45 McKesson \& Robbins, Inc., 1940 SEC LEXIS, at *19-20.

$46 I d$. at $* 23$ (wherein the SEC indicated that auditing procedures should include the inspection of inventory, and auditing steps previously viewed as optional should be accepted as normal auditing procedures for public company financial statements).

47 Phillip Barber, Bull in the China Market: The Gap Between Investor Expectations and Auditor Liability for Chinese Financial Statement Frauds, 24 DUKE J. COMP. \& INT'L L. 349, 379 
introduction of the accounting profession to the role of audit regulator.

\section{B. The Outside Directors as Auditor Overseers}

Revelations of accounting frauds at public companies and corresponding allegations of shortcomings in the performance of those auditing the financial statements continued to arise, despite the presence of the audit profession in the regulatory role of standard setter. ${ }^{48}$ These challenges came to a head in June 1970 , when the Penn Central Transportation Company ("Penn Central") unexpectedly declared bankruptcy, setting the bar as the largest bankruptcy to date in the nation's history. ${ }^{49}$ Penn Central had merged with another large railroad company, New York Central, in 1968, creating an entity that was expected to be a high quality, blue chip investment for investors. ${ }^{50}$ In reality, the company was hemorrhaging money soon after its formation as the result of poor planning, the declining use of railroads in the United States, the additional personnel expense mandated by the terms of the merger, and the overzealous efforts by Penn Central management to diversify with activities that were outside of the transportation industry. ${ }^{51}$ To disguise these losses, Penn Central executives pursued a policy of maximizing reported income wherein they encouraged creative accounting practices that transformed transactions with no substance into transactions that generated profits and hid expenses, resulting in financial statements that masked the company's precarious financial position. ${ }^{52}$

Penn Central's auditor, Peat, Marwick, Mitchell \& Co. ("Peat"), was aware of the income maximization policy at Penn Central and was often consulted about these accounting practices. ${ }^{53}$ Peat acquiesced to Penn Central's management with respect to these aggressive accounting decisions and stayed mute in its audit reports,

(2013) (describing the American Institute of Accountants' response to the need for audit standards: first by issuing bulletins to communicate audit standards, then releasing a set of standards establishing generally accepted audit standards in 1948).

48 See, e.g., Ernst \& Ernst, Accounting Series Release No. 248, 1978 SEC LEXIS 1451 (May 31,1978 ) (finding that the auditors of Western Equities, Inc. failed to perform their duties as outside auditors by certifying the company's 1964 and 1965 financial statements when the financial statements improperly included the earnings of acquired companies, and profits from a transaction that was not at arm's length); Fischer v. Kletz, 266 F. Supp. 180 (S.D.N.Y. 1967) (involving shareholder allegations that the outside auditor of Yale Express failed to disclose misleading information contained in the company's annual reports and various interim reports).

49 Staff of SEC, 92D Cong., The Financial Collapse of the Penn Central Company, at iii, 1 (Subcomm. Print 1972).

50 Id. at 1-2; Jeffrey N. Gordon, The Rise of Independent Directors in the United States, 19502005: Of Shareholder Value and Stock Market Prices, 59 STAN. L. REV. 1465, 1515 (2007).

51 STAFF OF SEC, supra note 49, at 3-4.

52 Id. at 4.

53 Peat, Marwick, Mitchell \& Co., Exchange Act Release No. 11517, 1975 SEC LEXIS 2516 (July 2, 1975). 
despite its knowledge of the overstatements contained therein.

Peat was disciplined by the SEC for its audit failures in this matter, as well as four others. ${ }^{54}$ In response to these missteps, the SEC, joined by the AICPA and the NYSE, made recommendations for the establishment of audit committees to serve as an independent line of communication between corporate management and boards of directors. ${ }^{55}$ More importantly, audit committees were tasked to appoint, and communicate directly with, outside auditors. In essence, corporate management was leveraged to strengthen the ability of outside auditors to withstand the pressure of corporate insiders interested in communicating financial success in the company's financial statements. ${ }^{56}$

\section{Deputizing the Audit Profession}

Revelations of a massive financial fraud at Equity Funding Corporation of America ("Equity Funding") in 1973 again put public company auditors in the cross hairs of regulation. Equity Funding, incorporated in 1960, was a NYSE-listed company primarily engaged in marketing and selling insurance products. ${ }^{57}$ Between 1968 and 1971, the company engaged in a massive fraud to hide its operating losses by creating fictitious insurance policies that generated fake insurance premium payments that the company claimed as income on its books. ${ }^{58}$ The company's outside auditor, a small firm of Wolfson, Weiner, Ratoff, \& Lapin, was aware of inconsistencies and unsupported information in the company's financial statements, but nonetheless issued unqualified audit reports on the company's financials. ${ }^{59}$ The three accountants involved in the poorly performed audits were criminally convicted of fraud and sentenced to prison terms. ${ }^{60}$

Once again, the accounting profession was under the microscope; this time, it denied wrongdoing. Instead, the AICPA adopted standards permitting the disclaimer of auditor responsibility for verifying certain items in a company's financial statements. ${ }^{61}$ Congress, however, did react. A Congressional staff report was issued in December 1976 describing its perspective on the accounting industry. ${ }^{62}$ This report, which became known as the Metcalf Report, found the audit

54 Id.

55 Sanford Kreiger, Recent Developments in Audit Committees, N.Y. L.J., Nov. 2, 1999, at 24.

56 Id.

57 Ronald L. Soble \& Robert E. Dallos, The Impossible Dream: The Equity Funding Story: The Fraud of THE Century 38, 158 (1975).

58 Id. at $19,158$.

59 See United States v. Weiner, 578 F.2d 757, 763 (9th Cir. 1978).

60 Barber, supra note 47 , at 381.

${ }^{61}$ Id. at 381-82.

62 Staff of S. Subcomm. On Reps., Acct., \& Mgmt., 94TH Cong., The Accounting Establishment: A Staff Study 7 (Comm. Print 1976) (“Serious questions have been raised 
industry in dire need of auditors of public companies that could be independent of corporate client interests and embrace their obligations to the public. The report further derided inclinations of the SEC to relegate responsibility for quality accounting to the industry itself:

To an astounding degree, the SEC has permitted, and even insisted upon, establishment of accounting standards which have substantial impact on the Federal Government and the public by self-interested private accounting organizations. The result has been an extraordinary delegation of public authority and responsibility to narrow private interests. ${ }^{63}$

The Metcalf report described the lack of public information on the largest accounting firms that were performing audits for most public companies in the United States, and noted the importance of auditing standards in establishing the responsibilities of public company auditors. ${ }^{64}$ The report urged greater public discourse on audit standards being adopted by the AICPA, the entity with standardsetting authority at that time. It also urged the establishment of a self-regulatory agency to oversee auditors. ${ }^{65}$

The audit profession rallied mightily to avoid government oversight and it ultimately succeeded. In 1977, the AICPA formed the Division for CPA Firms, which consisted of two sections-one for firms providing services to public companies, those under the oversight of the SEC (the "SEC Practice Section" or "SECPS"), and one for private companies (the "Private Companies Practice Section"). ${ }^{66}$ The Division was formed in direct response to auditing failures in the industry and the threat of government regulation, which the accounting industry feared as a regime of policing and punishment. ${ }^{67}$ The industry believed an

concerning the independence and competence of the 'Big Eight' accounting firms and other independent auditors. Those questions have arisen because of accounting and auditing problems involved in the Penn Central collapse, the Equity Funding fraud, improper and illegal activities by Gulf Oil Corp. and Northrop Corp., and the many other abuses by corporations which have come to public attention in recent years. A common complaint in such cases has been, 'Where was the independent auditor?"”).

${ }^{6}$ Id. at 17.

${ }^{64} I d$. at $20-21$.

65 Andrew W. Reiss, Note, Powered by More Than GAAS: Section $10 A$ of the Private Securities Litigation Reform Act Takes the Accounting Profession for a New Ride, 25 HofSTRA L. REV. 1261, 1281 n.109 (1997).

66 U.S. Gov'T Acct. OfF., GAO/AIMD-96-98, The Accounting Profession: Major ISSUES: PROGRESS AND CONCERNS 12 (1996) ("In 1977, the AICPA instituted a voluntary peer review program that included reviewing public accounting firms' systems of quality control for their accounting and auditing practices, creating the SEC Practice Section within the AICPA to administer the program, and creating the Public Oversight Board to oversee the SEC Practice Section and to represent the public interest.").

67 Pub. Oversight Bd., SEC Prac. Section, Am. Inst. of Certified Pub. Accts., Audit Quality: The Profession's Program 5-7 (1985) (describing the establishment of the Division 
environment of professional guidance and support would be more effective in improving the quality of audits and fostering reliable and accurate financial statements.

AICPA member firms could choose to join the SEC Practice Section, the Private Companies Practice Section, both sections, or neither section. ${ }^{68}$ The primary objectives of the SEC Practice Section were (1) to use self-regulatory mechanisms such as oversight and education to effectuate high standards of performance in the audits of public companies under the oversight of the SEC; and (2) to inspire public confidence in the ability of the accounting profession to self-correct without the need for greater governmental intrusion into the practice. ${ }^{69}$

The Division for CPA Firms was the structure used to identify the firms that would be subject to the self-regulatory model, and the corpus for execution on the mission of self-policing. The Public Oversight Board ("POB") was constituted in 1978 to represent the interests of the public by serving as an independent overseer of the SEC Practice Section's work. ${ }^{70}$ A core function of the SEC Practice Session was to establish a program whereby members would review, assess, and deliver feedback on the SEC-related work performed by their audit firm peers (referred to as "peer reviews"). ${ }^{71}$

It is notable that the Division regulated the accounting profession at the firm level, instead of at the individual CPA level. This was a meaningful shift from the traditional paradigm of regulating professional practices by influencing the behavior of individual accountants. ${ }^{72}$ This approach made the firm responsible for

for CPAs as a response to public and Congressional criticism; and characterizing government regulation as punitive, while casting self-regulation as focused on education and communication).

68 Robert L. Bunting, Transparency: The New Peer Review Watchword, CPA J., Oct. 2004, at 6, 8 (noting that the voluntary nature of membership in the sections of the Division for CPA Firms weakened arguments that the peer review processes adopted by each were effective policing mechanisms).

69 Pub. Oversight Bd., SeC Prac. Section, Am. Inst. of Certified Pub. Accts., ANNUAL REPORT 1982-1983, at 17 (1983) [hereinafter ANNUAL REPORT 1982-1983] (discussing the importance of the publicizing the SEC Practice Section's programs to strengthen the credibility of the profession and motivate more firms to voluntarily submit to its oversight).

70 Roberta S. Karmel, Realizing the Dream of William O. Douglas-The Securities and Exchange Commission Takes Charge of Corporate Governance, 30 DEL. J. CORP. L. 79, 115 (2005).

71 Timothy J. Fogarty, The Imagery and Reality of Peer Review in the U.S.: Insights from Institutional Theory, 21 ACCT., ORGS. \& SOC'Y 243, 243 (1996) (“[T] he primary means used by the accountancy profession to restore social confidence in their core work has been peer review programs. The inspection of audit work performed by one practitioner by another practitioner has been the main technology whereby professional self-regulation occurs.").

72 Pub. Oversight Bd., SeC Prac. Section, Am. Inst. of Certified Pub. Accts., ANNUAL REPORT 1983-1984, at 7 (1984) [hereinafter ANNUAL REPORT 1983-1984] (describing the innovative structure of the Division for CPA Firms in focusing on accounting firms instead of individual accountants). 
establishing and monitoring the practices of its accounting professionals. The creation of the POB was also a notable event as it introduced a new resource into the mix of participants involved in the endeavor to develop effective audit regulation-independent monitors from outside the industry to police the profession's efforts to police itself. ${ }^{73}$ The POB was to be comprised of persons of prominence and high integrity working outside of the accounting industry in positions such as former public officials, lawyers, bankers, academics, and business professionals. The POB also included staff and administrative support for the POB members. ${ }^{74}$ The POB's independence from accounting industry influence was to be maintained through its non-accounting leadership, and funding sourced from the dues paid by the individual SECPS members, instead of AICPA funds. ${ }^{75}$ The POB was to monitor the peer review and special investigations committees of the AICPA's executive committee, and serve as a liaison to the SEC on efforts to improve the audit profession. ${ }^{76}$ The audit profession and the SEC would have to let the passage of time establish the success of the regulatory combination of self-regulation with an overlay of supervision by a panel of non-accountant professionals that would deliver the desired effect of improved audits.

Less than a decade after the SEC Practice Section came into existence, a new public scandal reprised the question of the credibility of the audit profession. This time, the scandal centered around allegations of "opinion shopping," the act of changing auditors to secure an opinion that management's proposed accounting treatment of a particular transaction or event is consistent with generally accepted accounting principles even though the treatment obfuscates the true economic substance of the transaction or event. ${ }^{77}$ The scandal started with Penn Square, a financial institution that had received a qualified report on from its outside auditor, Arthur Young Co., for its fiscal year ended 1980 financial statements. ${ }^{78}$ Penn Square fired the audit firm and hired Peat Marwick, which issued a clean bill of health in the form of an unqualified opinion on the bank's financial statements for the subsequent year. The bank became insolvent three months later. ${ }^{79}$ The collapse of Penn Square had a domino effect on other banks with which it had done business;

73 O'Connor, supra note 36, at $562 \&$ n.234.

74 Framework for Enhancing the Quality of Financial Information Through Improvement of Oversight of the Auditing Process, Securities Act Release No. 8109, Exchange Act Release No. 46120, Investment Company Act Release No. 25624, 67 Fed. Reg. 44,964, 44,976-77 (June 26, 2002) [hereinafter Framework for Enhancing the Quality of Financial Information].

75 Mark, supra note 16, at 1110-12.

76 ANNUAL REPORT 1982-1983, supra note 69, at 24 (describing the functions of the POB).

77 Dale R. Rietberg, Auditor Changes and Opinion Shopping-A Proposed Solution, 22 U. MiCH. J.L. REFORM 211, 214 (1988).

78 Mindy Jaffe Smolevitz, Note, The Opinion Shopping Phenomenon: Corporate America's Search for the Perfect Auditor, 52 BROOK. L. REV. 1077, 1110 n.154 (1987).

79 Id. 
that effect was of such significance that it generated substantial losses at major banking institutions, like Chase Manhattan Bank of New York and Continental Illinois. $^{80}$

The SEC did not address auditor misconduct with respect to Penn Square, but in 1983, the Commission settled an administrative proceeding brought against two savings and loan companies that had been facing significant financial losses as a result of failed attempts to hedge against a sudden drop in interest rates in $1982 .{ }^{81}$ Both institutions were advised by their respective outside auditors that they could not defer these losses to future periods. The companies terminated their respective outside auditors and hired the accounting firm of A.M Pullen \& Co. ("Pullen"), which raised no objections to the deferral of losses that the prior auditors had rejected. The SEC ordered the two banks to restate their financials to correct the erroneous accounting treatment, ${ }^{82}$ and sanctioned three partners at Pullen in connection with the matter. ${ }^{83}$ The SEC noted that these individuals concluded that the accounting treatment rejected by prior auditors was acceptable, despite indications to the contrary in their own analysis, internal guidance at the firm, relevant accounting guidance existing at the time of the work, and the conclusions reached by the banks' prior auditors. ${ }^{84}$ The Commission was emphatic in its order that the practice of opinion shopping adversely impacted the integrity of the audit profession. ${ }^{85}$ The Commission also solicited comments on possible rulemaking to address the unsavory practice. ${ }^{86}$

Risks to the reliability of audited financial statements posed by the practice of opinion shopping were reflected in rulemaking comments solicited by the SEC on this topic as well as hearings convened in the House of Representatives to discuss the SEC's activities regarding the practice. ${ }^{87}$ The AICPA's progress in gaining effective oversight of auditors was again in the public eye. ${ }^{88}$ At the conclusion of this particular hullabaloo, the participants involved in audit regulation remained unchanged; however, both the AICPA and the SEC modified their respective rules

80 Eric G. Behrens, Note, Classification of Loan Participations Following the Insolvency of a Lead Bank, 62 TEX. L. REV. 1115, 1116-18 (1984).

81 Accounting for Gains and Losses Incurred in Connection with Certain Securities Transactions, Exchange Act Release No. 20266, 1983 SEC LEXIS 599 (Oct. 6, 1983).

82 Id.

83 Wade, Exchange Act Release No. 21095, 1984 SEC LEXIS 1275, at 1093-94 (June 24, 1984).

84 Id. at 1090.

85 Id. at 1092.

86 Daniel L. Goelzer, The SEC and Opinion Shopping: A Case Study in the Changing Regulation of the Accounting Profession, 52 BROOK. LAW REV. 1057, 1065 (1987).

87 Rietberg, supra note 77, at 215.

88 Gary Klott, Auditors Face U.S. Scrutiny, N.Y. Times, Feb. 18, 1985, at D1. 
to create additional protections against the insidious practice of opinion shopping. ${ }^{89}$ The SECPS continued to implore Congress to refrain from using its legislative powers to address the perceived failings of the industry to police itself. ${ }^{90}$

By 2002, the regulatory hypothesis that self-regulation with independent oversight by non-accountants would be effective to police public company auditors had been disproven. The rising stock market of the 1990s and the propensity for large companies to achieve successful growth through acquisitions created an environment ripe for disappointment in public company auditors. ${ }^{91}$ That disappointment came in like a wrecking ball when the public learned that Enron's financial statements were being questioned by the SEC and that Enron's outside auditors had begun shredding its records on Enron audits after hearing news of the inquiry. ${ }^{92}$ Additional wrecking balls followed for the accounting industry, as accounting frauds at major corporations like WorldCom, Inc. and Tyco unfurled, ${ }^{93}$ demonstrating that public company auditors had left their posts as gatekeepers to join their corporate clients in profit maximization and investor misdirection. Investors suffered mightily during this era of discovery of the true financial condition of companies that were instrumental to their financial growth. ${ }^{94}$

Despite years of assurances from the AICPA and the SEC that the components of self-regulation and independent non-governmental oversight could achieve effective regulation of public company auditors, the financial scandals from 2000 to 2002 proved otherwise. The start of the 21 st century was marred by restatements of financial condition by public companies and loss of investment gains in the stock market, leading to a reactive finger-pointing exercise in which the audit profession was yet again targeted for its failure to deliver reliable reports on the financial

89 Rietberg, supra note 77, at 228. The SEC Practice Section of the AICPA adopted additional membership requirements mandating that firms establish standards for rendering advice to non-audit clients seeking their expertise, and the SEC amended its disclosure rules around public company reporting of changes in accountants. $I d$.

90 Pub. Oversight Bd., SeC Prac. Section, Am. Inst. of Certified Pub. Accts., ANNUAL REPORT 1985-1986, at 35 (1986) ("Thus, we strongly urge that . . Congress refrain from adopting any legislation further regulating the profession until it evaluates the nature and effectiveness of the profession's responses to the challenges it now confronts.").

91 Neil H. Aronson, Preventing Future Enrons: Implementing the Sarbanes-Oxley Act of 2002, 8 STAN. J.L. BUS. \& Fin. 127 (2002).

92 Kathleen F. Brickey, From Enron to WorldCom and Beyond: Life and Crime After SarbanesOxley, 81 Wash. U. L.Q. 357, 357 (2003).

93 Marianne M. Jennings, Restoring Ethical Gumption in the Corporation: A Federalist Paper on Corporate Governance - Restoration of Active Virtue in the Corporate Structure to Curb the "YeeHaw Culture" in Organizations, 3 Wyo. L. ReV. 387 (2003) (detailing the nature of the accounting frauds executed at WorldCom and Tyco).

94 Aronson, supra note 91, at 127 ("From March, 2000 through September 30, 2002, the U.S. stock markets lost half of their market capitalizations, reducing investors' net worth by almost $\$ 8.5$ trillion.”). 
condition of the public companies it had audited. ${ }^{95}$

\section{Creating a New Regulator}

After the Enron debacle, Congress set out to perform its own assessment of the composition of influencers involved in the regulation of auditors responsible for reviewing the financial statements at public companies. ${ }^{96}$ That assessment resulted in a series of reforms wrapped into one piece of legislation, the Sarbanes-Oxley Act of 2002 ("Sarbanes-Oxley," "S-Ox," or the "Act"). The Act significantly altered the formula for audit oversight by creating the PCAOB, a private, nonprofit corporation. ${ }^{97}$ At the time of Congress's action, the SEC had already developed a blueprint for a new regulatory approach to replace the self-regulatory regime comprised of the SECPS and the POB. The approach proposed by the SEC in 2002 would permit the SEC to designate private, not-for-profit entities as "public accountability boards," or "PABs," that would be responsible for overseeing accounting firms engaged in auditing public companies. ${ }^{98}$ The SEC's proposal was transparent in its intent to address those operational characteristics of self-regulation that it perceived as having contributed to the financial failures at the turn of the millennium. ${ }^{99}$ The SEC hypothesized that the self-regulatory approach to overseeing auditors had failed for reasons that included unreliable funding of the oversight function, the performance of inconsistent peer reviews by public accounting firms, the voluntary nature of SECPS oversight, ineffective sanctions, and nonpublic proceedings. ${ }^{100}$

Congress chose to take the reins on this issue via legislation, rather than allowing an executive agency to address the matter through rulemaking. Its solution, however, reflected much of the substance of the SEC's detailed plan relating to revised oversight. ${ }^{101}$ Scholars have considered the question of whether federal

95 See generally M. Thomas Arnold, "It's Déjà Vu All Over Again" Using Bounty Hunters to Leverage Gatekeeper Duties, 45 TULSA L. REV. 419 (2010); John C. Coffee, Jr., What Caused Enron? A Capsule Social and Economic History of the 1990s, 89 CORNELL L. REV. 269 (2004).

96 Staff Of S. Comm. On Gov't Affairs, 107Th Cong., Financial Oversight of Enron: The Sec and Private-Sector Watchdogs 84-89 (Comm. Print 2002) (noting the various public and private sector entities involved in monitoring the activities of Enron, and congressional efforts to examine the performance of each in carrying out their duties with respect to Enron).

97 Nagy, PCAOB, supra note 2, at 366-67.

98 Framework for Enhancing the Quality of Financial Information, supra note 74.

99 Id. at 44,967-68.

100 Id. at 44,968.

101 David Ruder, Yuji Sun \& Areck Sycz, The Securities and Exchange Commission's Pre-and Post-Enron Responses to Corporate Financial Fraud: An Analysis and Evaluation, 80 NoTRE DAME L. REV. 1103, 1111 (2005). 
legislation was the right vehicle to accomplish audit oversight reform, ${ }^{102}$ which proved to be a prophetic consideration given the subsequent challenges to the constitutionality of the legislatively-created PCAOB. ${ }^{103} \mathrm{~S}-\mathrm{Ox}$ deviated from the SEC's suggested approach as it related to the oversight of auditors of public companies by creating one private, not-for-profit agency that would report to the SEC. ${ }^{104}$

Since its formation, the PCAOB has been the subject of criticism from constituents both inside and outside of the agency. ${ }^{105}$ Moreover, despite the legislative reforms implemented in 2002, allegations of financial irresponsibility and audit failures at public companies continue to generate public dialogue about the effectiveness of the agency. ${ }^{106}$ Finally, the Trump administration raised the question of whether the agency's overlapping authority with the SEC represents an opportunity to generate regulatory efficiency by combining the agencies. ${ }^{107}$

By enacting S-Ox, Congress has largely delivered the regulatory functions of

102 Joan MacLeod Heminway, Rock, Paper, Scissors: Choosing the Right Vehicle for Federal Corporate Governance Initiatives, 10 FORDHAM J. CORP. \& FIN. L. 225 (2005) (describing the need for analysis of determinations as to the appropriate body to undertake federal corporate governance reforms).

103 See Free Enter. Fund v. PCAOB, 561 U.S. 477 (2010).

104 Ruder et al., supra note 101, at 1111 ("The Sarbanes-Oxley legislation codified the substance of the Commission's PAB proposal by establishing the Public Company Accounting Oversight Board (PCAOB)....”).

105 Lynn E. Turner, Reforming the Auditing Profession, CPA J., Feb. 2020, https://www. cpajournal.com/2020/03/04/reforming-the-auditing-profession/ (discussing ongoing shortcomings in the audit profession regarding lack of independence, transparency, independent governance, and quality); Colleen Honigsberg, The Case for Individual Audit Partner Accountability, 72 VAND. L. REV. 1871, 1871 (2019) (asserting that "[d] espite repeated regulatory interventions, accounting failures continue to persist in companies around the world."); J. Robert Brown, Jr., Bd. Member, PCAOB, Statement Regarding the PCAOB's Revised Research and Standard-Setting Agendas: Reducing Credibility, Accountability and Confidence in the Financial Reporting Process (Oct. 13, 2020) (criticizing the agency's research and standard-setting agenda as inadequately reflecting the views of investors and posing a danger to the credibility of the agency itself).

106 See, e.g., Michael Whitmire, Audits Are Broken. Here's a Radical Way to Fix Them, CFO.COM (Nov. 27, 2019), https://www.cfo.com/auditing/2019/11/audits-are-broken-heres-aradical-way-to-fix-them/ (attributing the failure of the PCAOB to prevent more recent accounting failures, such as those investigations regarding UnderArmour and Mattel, to the fact that the agency examines audits performed by auditors only after the audit has occurred).

107 See Maurer \& Kiernan, supra note 6 (reporting Rep. Bill Huizenga's view that a conversation about consolidating the PCAOB into the SEC is necessary); Jason Bramwell, Could We Soon Be Living in a PCAOB-less World?, GOING CONCERn (Feb. 11, 2020), https://www. goingconcern.com/could-we-soon-be-living-in-a-pcaob-less-world/ (citing a scholar's concern about the duplication in standard-setting responsibilities between the PCAOB and standard setters outside of the realm of public company audits); Peterson, supra note 11 (discussing the agency's lack of credibility and events suggesting that the PCAOB has not contributed to improved audit quality). 
the SEC Practice Section and the POB to the PCAOB, with modifications driven by 20/20 hindsight of such financial debacles as Enron and WorldCom, in yet another attempt to manufacture an antidote for auditor abdication of gatekeeping duties. In sum, the PCAOB is a reactionary, rather than a progressive, model that has failed to meaningfully evolve after almost two centuries in existence. A progressive perspective at a granular level is necessary to get to the kernel of effective audit oversight.

\section{AFFIXING THE LENS OF REGULATORY THEORY}

\section{A. The Rubric of Regulation}

Regulatory entities, whether governmental or industry-driven, typically rely on three mechanisms to achieve their respective missions-standard setting, monitoring, and enforcement. ${ }^{108}$ Standard setting articulates the objectives that the regulated entities are expected to achieve; it establishes and provides an overall direction for the industry's composition. ${ }^{109}$ Monitoring reflects the information gathering activity of the regulator-it seeks to understand how the regulated entities are performing. ${ }^{110}$ Compliance assessments and enforcement activities are tools designed to modify the behavior of regulated entities. ${ }^{111}$

The PCAOB is obligated by the Sarbanes-Oxley Act to set standards for public company audits, ${ }^{112}$ a role previously carried out by the AICPA's Auditing Standards Board, under the oversight of the Public Oversight Board. ${ }^{113}$ The PCAOB is mandated under the Act to inspect audits of public companies performed by accounting firms, which audits serve as the PCAOB's primary monitoring

108 See, e.g., Fabrizio Cafaggi, The Many Features of Transnational Private Rule-Making: Unexplored Relationships Between Custom, Jura Mercatorum and Global Private Regulation, 36 U. PA. J. INT'L 875, 908-09 (2015) (describing the typical functions of the regulatory process as "standard setting, monitoring, and enforcement"); Sharon Yadin, E-Regulation, 38 CARDOZO ARTS \& ENT. L.J. 101, 130 (2020) (noting that individualized regulatory contracts can reflect standard-setting, monitoring, or enforcement); Jodi L. Short, The Paranoid Style in Regulatory Reform, 63 HASTINGS L.J. 633, 666-67 (2012) (describing standard setting, monitoring, and enforcement as government functions that are allocated to regulatory entities in self-regulation).

109 See Martin Lodge \& Kai Wegrich, Managing Regulation: Regulatory ANAlysis, POlitics AND POLICY 13-14 (2012) (describing the functions of standard setting, monitoring, and enforcement).

110 Id.

111 Id.

112 Faith Stevelman, Globalization and Corporate Social Responsibility: Challenges for the Academy, Future Lawyers, and Corporate Law, 53 N.Y.L. SCH. L. REV. 817, 848 n.132 (2008/2009).

113 Lawrence A. Cunningham, The Sarbanes-Oxley Yawn: Heavy Rhetoric, Light Reform (And It Just Might Work), 35 ConN. L. ReV. 915, 943 (2003). 
mechanism; ${ }^{114}$ the SECPS arranged for audit firms to examine each other under a peer review process. ${ }^{115}$ Finally, both the PCAOB and its predecessor were authorized to enforce compliance by regulated firms, ${ }^{116}$ although criticism has been levied against both the PCAOB and its predecessor SECPS regarding lax enforcement efforts. $^{117}$

The Sarbanes-Oxley Act provided the core elements of regulation in its design of the PCAOB. ${ }^{118}$ Yet, the PCAOB is under a barrage of criticism, as described above, for failing to exert its full regulatory prowess. How does regulatory theory explain why this oversight agency, created with all the requisite components of effective regulation, nonetheless produces such significant and credible reactions of dissatisfaction and disappointment?

One easy explanation is that the agency's design is adequate, but its performance (or lack thereof) has triggered a negative response from its vested constituents. In the lingo of regulatory theorists, the PCAOB may have lost "democratic legitimacy," generally defined as involving three core concepts: transparency in processes and decision-making, inclusiveness in considering the perspectives of those impacted by its decisions, and accountability for its decisions and results achieved. ${ }^{119}$ Scholars have explicitly and implicitly levied criticism against the $\mathrm{PCAOB}$ for its lack of transparency, noting that the agency is not burdened with the strictures of the Administrative Procedures Act, the Freedom of Information Act, and the Government in Sunshine Act. ${ }^{120}$ While democratic legitimacy could be an element of the PCAOB's challenges, a more detailed analysis, tailored to the operative activities of auditor oversight, is necessary to uncover the roadblocks to the agency's efficacy.

114 A.C. Pritchard, The Irrational Auditor and Irrational Liability, 10 LEWIS \& CLARK L. REV. 19, 33 (2006).

$115 \mathrm{Id}$. at 30.

116 Id. at 35.

117 See Michael Cohn, PCAOB Hits Pause on Setting Up New Outside Advisory Groups, ACCT. TODAY (June 22, 2021, 3:56 PM), https://www.accountingtoday.com/news/pcaob-hits-pauseon-setting-up-new-outside-advisory-groups (describing complaints about the drop in enforcement actions at the PCAOB); Mark, supra note 16, at 1110 (noting the failure of the oversight body of the SECPS - the POB - to sanction any major accounting firm during its existence).

118 Pritchard, supra note 114, at 33 ("There can be little question that the PCAOB's scope of regulatory authority is adequate to the task set for it by Congress.").

119 Rudder eT AL., supra note 8 at 46; see also Anna Spain, The U.N. Security Council's Duty to Decide, 4 Harv. NAT'L SeC. J. 320, 336 (2013) (describing a proposal for reform of the U.N. Security Council that focused on enhancing the agency's "accountability, transparency and inclusiveness ... with a view to strengthening its legitimacy and effectiveness").

120 See Kimberly N. Brown, Presidential Control of the Elite "Non-Agency", 88 N.C. L. REV. 71, 127 (2009); see also Nagy, PCAOB, supra note 2, at 363. 


\section{B. The Role of Verifiability in the Auditor Oversight Regime}

My path to discerning the successful components of effective auditor oversight starts where the authority to regulate an accounting firm typically begins-I focus on the mechanism deployed to determine those accounting firms that will be subjected to auditor oversight. The SECPS and its successor, the PCAOB, were formed in response to concerns about a discrete subsection of the accounting profession-firms involved in auditing the financial statements of public companies. Identifying those firms that should be subject to oversight is an element of the regulatory theory of verifiability, defined as "the capacity to monitor compliance with regulatory requirements." ${ }^{" 121}$ Scholars have recognized the role of verifiability of compliance in various industries, including artificial intelligence, ${ }^{122}$ environmental protection, ${ }^{123}$ and family law. ${ }^{124}$ Verifiability, therefore, is an important part of the dialogue on formulating sound auditor regulation.

Obtaining verifiability for all auditors of public companies has been a historical challenge to oversight of the audit industry. Verifiability, in the form of identification of accounting firms to be subjected to oversight, was implemented maladroitly by the SEC Practice Section, as its approach was simultaneously overinclusive and underinclusive. Verifiability was overinclusive because it encompassed all accounting firms, regardless of whether they actually audited public companies. ${ }^{125}$ The SECPS's rules required firms seeking membership to submit membership applications, but any CPA firm that agreed to comply with its membership requirements was permitted to join. ${ }^{126}$ This open-door policy was adopted to increase the number of member firms in the practice section, purportedly

121 Markell \& Glicksman, supra note 19, at 18.

122 Michael Guihot, Anne F. Matthew \& Nicolas P. Suzor, Nudging Robots: Innovative Solutions to Regulate Artificial Intelligence, 20 VAND. J. ENT. \& TECH. L. 385, 437 (2017) (describing a proposed approach to regulation of AI reflecting the need for policies that incorporated "verifiability of compliance").

123 See David L. Markell, The Role of Deterrence-Based Enforcement in a "Reinvented" State/Federal Relationship: The Divide Between Theory and Reality, 24 HARV. ENV'T L. REV. 1, 10 n.31 (2000) (describing scholarship in the area of environmental protection that considers the identification of regulated parties and monitoring compliance as elements of the enforcement aspect of regulation).

124 See Elizabeth S. Scott \& Robert E. Scott, From Contract to Status: Collaboration and the Evolution of Novel Family Relationships, 115 COLUM. L. Rev. 293, 359 (2015) (proposing a licensing or registration approach for purposes of delivering benefits to non-traditional families that would otherwise pose verifiability issues for regulators because of the difficulty in independently identifying such families).

125 SeC Prac. Section, Am. Inst. of Certified Pub. Accts., SeC Practice Section REFERENCE MANUAL $\$ 1000.04$ (14th ed. 2000) (“All CPA firms are eligible for membership in the Section even though they do not practice before the SEC.”).

126 Id. 
providing evidence to the government and the public that the audit profession was supportive of (and willingly engaged in) self-regulatory efforts. ${ }^{127}$ As a result of its open-admission policy, the SECPS maintained a steady population of member firms that did not audit SEC companies. Between 1980 and 1988, an average of 54\% of the SECPS's member firms had no SEC clients. ${ }^{128}$ The SECPS nonetheless made lemons into lemonade by reviewing portions of the firms' audits of private companies. $^{129}$

Rejection of self-regulation by certain firms engaged in auditing public companies further hampered compliance verifiability by the SECPS and was an ongoing source of frustration for the organization. ${ }^{130}$ During the period between its inception and 1988, the SECPS lowered the membership requirements, reduced membership dues, alleviated requisite insurance coverage minimums, removed the obligation to report the names of SEC clients, and launched a membership campaign, all to entice firms engaged in auditing public companies into the sphere of regulation. ${ }^{131}$ The SEC resorted to the bully pulpit to try to encourage more firms to join the SECPS. ${ }^{132}$ The SECPS and the Private Companies Practice Section jointly hired a public relations firm to increase membership and educate the public on the importance of membership to service quality. ${ }^{133}$ Faced with the risk that the SEC would move forward with its own proposal to provide oversight of public

127 See Pub. Oversight Bd., SEC Prac. Section, Am. Inst. of Certified Pub. Accts., ANNUAL REPORT 1981-1982, at iv (1982), wherein the Chairman of the POB described the Board's view that SECPS membership evidenced the industry's dedication to self-regulation.

128 See Public Oversight Board Annual Reports for years ended 1980 to 1988, indicating that the number of SEC Practice Section firms with and without SEC clients for each of those periods, available at https://egrove.olemiss.edu/aicpa_arprts/.

129 See, e.g., Am. InSt. Of Certified PUb. ACCTS., ANNUAl Report 1979-1980, at 2 (1980) (explaining the "report reviews" that would be performed on firms that had no SEC engagements).

130 See, e.g., ANNUAL REPORT 1983-1984, supra note 72, at 22 ("The Board shares the view of the SEC as reported in its most recent report to Congress: 'The Commission continues to believe that all accounting firms which audit public companies should join the SECPS.”').

131 See ANNUAL REPORT 1979-1980, supra note 129, at 23-24 (describing changes to the SEC Practice Section's membership requirements to attract additional firms to join); see also ANNUAL REPORT 1982-1983, supra note 69, at 28 (referencing several campaigns initiated to increase membership).

132 Harold M. Williams, Chairman, Sec. and Exch. Comm'n, Address at the AICPA Seventh National Conference on Current SEC Developments: The 1980s: The Future of the Accounting Profession (Jan. 3, 1980), wherein the Chairman noted, "The first unresolved issue relates to membership in the Section. On the positive side, it appears its 230 member firms audit almost 9,000 public companies ... Unfortunately, however, approximately 600 accounting firms that have at least one SEC audit client have not yet joined the SEC Practice Section."

133 See Pub. Oversight Bd., SeC Prac. Section, Am. Inst. of Certified Pub. Accts., ANNUAL REPORT 1984-1985, at 22 (1985). 
company auditors, ${ }^{134}$ the SECPS made membership in the section mandatory for all AICPA members engaged in the audit of SEC clients. ${ }^{135}$ This led to a dramatic rise in SECPS membership, from 519 firms in 1989 to 1,257 firms by August 1995. ${ }^{136}$ This membership requirement boosted the SECPS's oversight to cover $97 \%$ of audits being performed on public companies. Despite this increase, total verifiability remained elusive; certain accounting firms preferred to relinquish their AICPA membership, rather than their audits of public companies, to SECPS oversight. $^{137}$

In creating the PCAOB, Congress eschewed the SECPS's approach of membership as a form of verifiability, instead adopting "registration" as the vehicle by which the Board would define its audience of regulated firms. ${ }^{138}$ Congress replicated the self-regulatory approach of the SECPS by regulating the audit firm entities, instead of individual auditors. Moreover, the S-Ox legislation made $\mathrm{PCAOB}$ registration mandatory for a public accounting firm that prepares, issues, or participates in the preparation or issuance of any audit report with respect to any issuer, declaring, "It is unlawful for a firm that has not registered to continue to audit public companies. Conditioning eligibility to audit public companies on registration with the Board is the linchpin of the Board's authority."139

Unlike the SECPS, the PCAOB was backed by the strength of federal law to enforce verifiability as an element of its regulatory approach. Specifically, the Sarbanes-Oxley Act requires PCAOB registration of all firms engaged in auditing, or participating in the audits of, registered firms. ${ }^{140}$ Like the SECPS, however, the PCAOB experienced difficulties in achieving verifiability. In 2007, the SEC brought actions against 69 accounting firms for engaging in the audits of public companies

134 Am. Inst. of Certified Pub. AcCts., Annual Report 1988-1989, at 2-3 (1989) ("[T]he SEC may well implement its proposed program-adding new and inappropriate requirements for public company auditors.”).

135 Paul R. Brown, Jeanne A. Calderon \& Baruch Lev, Administrative and Judicial Approaches to Auditor Independence, 30 SETON HALl L. REV. 443, 449 (2000) (stating that all members of the AICPA auditing public companies were required by AICPA membership rules to be a member of the SECPS, effective 1990).

136 U.S. GOV'T ACCT. OfF., supra note 66, at 84.

137 Framework for Enhancing the Quality of Financial Information, supra note 74, at 44,992 ("We estimate, however, that approximately 80 accounting firms that are not currently members of the SECPS would likely become members of a [public accountability board] under the proposed rules. These firms are, we believe, smaller firms with one or two SEC clients that chose not to join the SECPS. Under the proposed rules, however, these firms would likely join a [public accountability board] in order to maintain those SEC clients.").

138 Stephen C. Gara \& Craig J. Langstraat, The Sarbanes-Oxley Act of 2002: A New Ballgame for Accountants, 34 U. MEM. L. REV. 73, 78-79 (2003).

139 Comm. on Banking, Hous., \& Urb. Affs., Public Company Accounting Reform AND InVESTOR Protection Act Of 2002, S. ReP. No. 107-205, at 7 (2002).

140 Nagy, Playing Peekaboo, supra note 2, at 1009. 
while not registered, in violation of federal law and PCAOB rules. ${ }^{141}$ A 2021 SEC administrative proceeding demonstrates that the SEC continues to police verifiability in furtherance of the PCAOB's oversight objective. ${ }^{142}$ Moreover, the PCAOB has denied the registration applications of over 20 accounting firms found to have performed audit-related activities while unregistered, in violation of S-Ox and Board rules, ${ }^{143}$ suggesting that verifiability presents an ongoing challenge to auditor oversight.

\section{Using Verifiability to Establish Expectations for Auditors}

The SECPS used the process of verifiability to establish standards of conduct for the firms under its oversight. The SECPS membership application required the applicant firm to agree to comply with all of the conditions of membership. ${ }^{144}$ Conditions of membership included having a majority of partners who were qualified to engage in public accounting, adhering to AICPA quality control standards, submitting to peer reviews, ensuring that all professionals obtained specified hours of continuing professional education, and filing an annual report with the SECPS that would be made available for public inspection. ${ }^{145}$ Further, members were required to maintain a certain level of liability insurance and pay assessed dues. ${ }^{146}$ The SECPS verifiability approach was sufficiently tailored to obligate member firms to comply with SECPS oversight and to further the goals of the organization in improving audit quality.

Reports issued by the SEC Practice Section demonstrate that it considered membership substantively significant. Membership was voluntary, and open to firms both engaged in practice before the SEC and firms not so engaged, yet the SECPS took steps to terminate membership of firms that did not abide by the membership criteria, including the obligations to submit annual reports, pay dues, and provide information to the SECPS in advance of a peer review. ${ }^{147}$ Failure to

141 SEC Charges 69 Audit Firms and Partners for Issuing Audit Reports While Not Registered with the PCAOB, SEC NEwS DIGEST (Sept. 13, 2007), https://www.sec.gov/news/digest/ 2007/dig091307.html.

142 See Knauth, Exchange Act Release No. 4207, 2021 WL 1297855 (Apr. 5, 2021) (alleging that neither the individual auditor nor its accounting firm were registered with the PCAOB at the time the audit firm issued an audit report on a public company).

143 See, e.g., Registration Application of BDO Italia S.p.A., PCAOB Release No. 102-2017002 (June 6, 2017); Registration Application of BDO AG, PCAOB Release No. 102-2012-003 (May 22, 2012); Registration Application of Davis, Graber, Plotzker \& Ward, LLP, PCAOB Release No. 102-2010-001 (Jan. 19, 2010).

144 ANNUAL REPORT 1979-1980, supra note 129, at 36.

145 Id. at 36-40.

146 Id. at 39.

147 For the fiscal year ended 1982, the SECPS terminated the SECPS membership of 24 firms on this basis, despite simultaneous concerns about the need to increase membership. See 
comply with such conditions of membership resulted in the removal of 30 firms between March 1980 and June 1983 from membership for failure to comply with administrative obligations to pay dues and file reports. ${ }^{148}$

The SEC Practice Section established verifiability by both requiring the firm to agree to comply with its rules, and by requiring the applicant firm to provide specified information about itself as part of the membership application process. ${ }^{149}$ The SECPS application process provided an additional mechanism for verifiability, as the information gathered was useful in determining the appropriate scope of monitoring firm compliance. For example, the SECPS process required applicant firms to identify their public company clients, and provide a description of the firm's internal organizational structure. ${ }^{150}$ Unfortunately, the SECPS subsequently eliminated these (and other) verifiability components from the membership application process in connection with its efforts to coax more public company auditors into regulatory oversight. ${ }^{151}$

In contrast to the SEC Practice Section, Congress imposed only one commitment upon firms seeking to register with the PCAOB for purposes of auditing public companies. The Sarbanes-Oxley Act required that each applicant firm agree to cooperate with any requests from the Board for documents or testimony, and to secure similar consents from individuals associated with the applicant firm. ${ }^{152}$ However, the requirement did not apply to accounting firms based outside of the United States. While S-Ox provided that foreign accounting firms would be subject to the statute to the same extent as a domestic accounting firm, ${ }^{153}$ S-Ox gave the PCAOB broad authority to exempt foreign accounting firms from any provisions of the legislation. ${ }^{154}$ The PCAOB used its exemptive authority under the Act to permit audit firms located outside of United States to withhold their agreement to provide documents and testimony to the Board during the

Pub. Oversight Bd., SeC Prac. Section, Am. Inst. of Certified Pub. Accts., Annual REPORT 1981-1982, at 19, 33 (1982) [hereinafter ANNUAL REPORT 1981-1982].

148 See Pub. Oversight Bd., SEC Prac. Section, Am. Inst. of Certified Pub. Accts., ANNUAL REPORT 1980-1981, at 16 (1980); ANNUAL REPORT 1981-1982, supra note 147, at 33; ANNUAL REPORT 1982-1983, supra note 69, at 15.

149 SEC PRAC. SECTION, supra note $125, \$ 1000.04$ (setting forth, as a criterion for membership, submission of a written application that is accompanied by information required to be reported annually by all member firms under $\$ 1000.08(\mathrm{~g}))$.

150 See Appendix 1 hereto summarizing the content of both the SEC Practice Section membership application and the PCAOB registration application.

151 ANNUAL REPORT 1981-1982, supra note 147, at 18.

152 Nagy, PCAOB, supra note 2, at 378.

153 Thomas C. Pearson, Creating Accountability: Increased Legal Status of Accounting and Auditing Authorities in the Global Capital Markets (U.S. and EU), 31 N.C.J. INT'L L. \& COM. REG. 65, 129 (2005).

154 Nagy, Playing Peekaboo, supra note 2, at 1018. 
application process, based on an assertion that providing such consent could violate the laws of the accounting firm's home country. ${ }^{155}$ This exception continues to undercut verifiability by curbing the ability of the PCAOB to monitor compliance of firms based in jurisdictions like China, where the PCAOB (and the SEC) is unable to exercise regulatory oversight due to asserted conflicts between the cooperation obligation mandated by $\mathrm{S}-\mathrm{Ox}$ and the home country laws of the applicant accounting firm. ${ }^{156}$ In sum, neither the PCAOB nor the SECPS has demonstrated effective dominion over verifiability at the commencement of their respective oversight relationships with individual public accounting firms.

\section{Using Verifiability to Establish Expectations for Investors}

SECPS membership, and now PCAOB registration, create expectations for investors, as an application requiring specific information relevant to auditing public companies must be submitted and reviewed. Yet, neither the SECPS, Congress, nor the $\mathrm{PCAOB}$ designed these verifiability processes to establish a standard for admission to their respective oversight regimes upon which public investors could rely. These entities required that the applications be approved, but failed to articulate tangible criteria for how adequacy of any particular firm's application was to be determined. ${ }^{157}$

PCAOB rules provide some information on this process. Specifically, its rules require that the Board determine whether approval of each application "is consistent with the Board's responsibilities under the Act to protect the interests of investors and further the public interest in the preparation of informative, accurate, and independent audit reports." 158

155 See id.

156 Yawen Li, Note, "The Shell Game": Reverse Merger Companies and the Regulatory Efforts to Curb Reverse Merger Frauds, 15 N.Y.U. J.L. \& Bus., 153, 180-81 (2018). In December 2020, the Holding Foreign Companies Accounting Act was signed into law, barring issuers whose audits were examined by the PCAOB from trading on U.S. exchanges. Larry Bergmann \& Robertson Park, What Trading Restrictions on China Mean for US Markets, LAW360 (Jan. 7, 2021, 5:51 PM), https://www.law360.com/articles/1342010/what-trading-restrictions-on-china-mean-forus-markets.

157 See SEC PRAC. SECTION, supra note $125, \$ 1000.04$ (providing that all CPA firms are eligible for membership in the SECPS and may attain membership by submitting a written application agreeing to abide by all membership requirements); Sarbanes-Oxley Act of $2002 \$ 102(\mathrm{c})(1), 15$ U.S.C. $\$ 7212$ (c) (1) (providing that the Board shall approve applications in accordance with its rules); Section 2. Registration and Reporting, PCAOB, at Rule 2106(a), https://pcaobus.org/about/rules-rulemaking/rules/section_2 (last visited Dec. 27, 2021) (stating that the Board will decide whether to approve a registration application based on determining whether registration of the firm is consistent with the Board's responsibilities under the Act to protect investors and further the public interest in the preparation of informative, accurate, and independent audit reports).

158 Section 2. Registration and Reporting, supra note 157, at Rule 2106(a). 
Guidance published by the PCAOB on its application process describes, by example, circumstances the Board might view as providing a basis for denial of a registration application. ${ }^{159}$ The guidance indicates that disapproval of a registration application could be deemed appropriate by the Board if the applicant firm violated the registration provisions of the Act or Board rules by engaging in conduct requiring $\mathrm{PCAOB}$ registration while not so registered, or having personnel who are legally precluded from participating in the audit of public companies pursuant to a disciplinary sanction such that there is a question as to whether the firm itself is able to participate in such audits. ${ }^{160}$ The guidance also proffers, as potential grounds for disapproval, specific conduct of a firm that was previously registered with the Board, withdrew, and seeks to re-register. ${ }^{161}$ Finally, the guidance indicates that the Board might also consider information learned about the applicant through its oversight processes. $^{162}$

Like the SECPS, the PCAOB has adopted an open-arms admission policy, allowing firms that are not involved in the audit of public companies to become associated with regulation of auditors. ${ }^{163}$ This approach was understandable from the SECPS's perspective, where participation in the SECPS and the Private Company Practice Section was considered evidence of acceptance of self-regulation by the accounting profession. ${ }^{164}$ Further, increased SECPS membership translated to increased funding for the independence mechanism of the self-regulatory scheme, as SECPS membership dues paid by accounting firms were used to fund the Public Oversight Board. ${ }^{165}$

This open-arms approach is less rational as it relates to the PCAOB. The Board's guidance on registration seems to justify the open admission policy as a nod to regulatory cooperation and the spirit of entrepreneurialism. Specifically, the guidance indicates that firms that are not engaged in the business of auditing public companies may register with the PCAOB to comply with the requirements of others

159 Frequently Asked Questions Regarding Registration with the Board, PCAOB Release No. 2003-011F, at 6 (Dec. 4, 2017) [hereinafter PCAOB, FAQ].

160 Id.

161 Id.

$162 I d$.

163 Id. at 4.

164 See ANNUAL REPORT 1983-1984, supra note 72, at 3, wherein the Chairman of the POB described the Board's view that SECPS membership evidenced the industry's dedication to selfregulation and improved audit services for clients.

165 Mark, supra note 16, at 1110. While funding the POB with fees paid by SECPS membership was intended to enhance the POB's independence from the accounting profession's influence in the form of the AICPA, the approach ultimately proved ineffective as the AICPA still controlled the POB's budget. See Nagy, Playing Peekaboo, supra note 2, at 994-95 (describing the AICPA's termination of funding of the POB after the POB made a decision with which the AICPA disagreed). 
regulators whose mission is unrelated to audits of U.S. public companies. ${ }^{166}$ The guidance also acknowledges that firms with no experience auditing public companies might nonetheless be interested in doing so. ${ }^{167}$ The guidance goes on to disclaim responsibility for all such firms, explaining that firms that are registered with the Board, but not engaged in activities for which registration is required, are completely excluded from regulation by the Board. ${ }^{168}$ This explanation highlights the dichotomy between the Board's mission and its registration approval process; it also highlights a significant deviation from the SECPS's approach, which performed some level of review of the audit work performed by its members on non-SEC registrants. ${ }^{169}$ The PCAOB's guidance affirms that firms registered for such reasons are still expected to pay the Board's annual fees and file required annual reports. ${ }^{170}$

The PCAOB has denied 46 registration applications since its inception in 2003. ${ }^{171}$ These denials were primarily focused on the inability of applicant firms to comply with rules requiring $\mathrm{PCAOB}$ registration, rather than concerns about the quality of audits performed by the firm. ${ }^{172}$ While the Board's 2017 guidance on registration indicates that registered firms without audit clients would still be subject to the requirements to pay annual fees and submit annual and special reports, the registration disapprovals suggest this policy statement was not enforced. The Board denied eight registration applications from firms on the basis that they had failed one or both annual requirements to pay fees and file reports while previously registered. ${ }^{173}$

166 PCAOB, FAQ, supra note 159, at 4 ("Some regulators have adopted rules requiring persons subject to their jurisdiction to use PCAOB-registered firms for specified services unrelated to audits of issuers, brokers, or dealers.").

167 Id.

${ }^{168} I d$. at 4-5 (stating that registration alone does not subject a firm to Board oversight, and the Board's regulatory processes will not be applied to firms that are not engaged in audits covered by its regulatory authority).

169 See, e.g., AM. INST. OF CeRTIFIED PUB. ACCTS., supra note 129, at 2 (describing the concept of "report reviews" that would be performed on firms that had no SEC engagements).

170 PCAOB, FAQ, supra note 159, at 4.

171 See PCAOB Registration Disapproval Notices, PCAOB., https://pcaobus.org/oversight/ registration/disapprovalnotices (last visited Dec. 27, 2021).

172 See id. (reflecting the disapproval of 36 registration applications due to the failure of the applicant firm to register with the PCAOB prior to engaging in audit activities for which registration was required).

173 See Registration Application of Vail \& Knauth LLP, PCAOB Release No. 102-2013-001 (Feb. 21, 2013); Registration Application of Ogbomo CPA, LLC, PCAOB Release No. 1022014-004 (Oct. 7, 2014); Registration Application of David R. Ramos, CPA, PCAOB Release No. 102-2014-002 (Mar. 6, 2014); Registration Application of Lawrence Hoffman, Certified Public Accountant, P.C., PCAOB Release No. 102-2014-001 (Jan. 28, 2014); Registration Application of Khalsa McBrearty Accountancy, LLP, PCAOB Release No. 102-2015-001 (Jan. 26, 2014); Registration Application of Morty Etgar, P.A., PCAOB Rel. No. 102-2015-002 (May 
Scholars have remarked upon the close resemblance between verification and certification, noting that verification can be used to substantiate marketing claims regarding quality. ${ }^{174}$ SECPS membership and PCAOB registration, respectively, raise concern that admission to these organizations could create misleading assumptions about the quality of the accounting firms that have achieved such status. Both the SECPS and PCAOB make the content of applications for membership and registration publicly available, ${ }^{175}$ potentially undercutting this concern through disclosure. PCAOB personnel have acknowledged the potential for confusion regarding the import of its generous admission practice, remarking publicly that the agency has adopted a "low bar" for registration eligibility. ${ }^{176}$ As a result, there are a significant number of firms registered with the PCAOB (and therefore authorized to audit public companies) that may lack the ability to do so competently. According to the Board's 2019 Annual Report, 1,796 firms were registered with the $\mathrm{PCAOB}$, but only 597 of them (33\%) engaged in audits of public companies requiring regulatory oversight. ${ }^{177}$ Unlike the SECPS, the Board undertakes no supervisory efforts with respect to these firms. ${ }^{178}$

The PCAOB's approach to verifiability has raised internal concern at the agency. In 2013, former Board member Jeanette Franzel publicly discussed the significant number of registered firms that were not subject to Board oversight. ${ }^{179}$ She indicated that the Board was considering this trend and potential confusion

18, 2015); Registration Application of Kingston Smith LLP, PCAOB Release No. 102-2016-001 (Dec. 13, 2016); Registration Application of GYL Decauwer LLP, PCAOB Release No. $102-$ 2018-001 (June 13, 2018).

174 Lesley K. McAllister, Regulation by Third-Party Verification, 53 B.C. L. Rev. 1, 3-4 (2012) (discussing the use of third parties — such as auditors or even the PCAOB itself-to certify compliance to the government, noting "third-party verification closely resembles third-party certification, used in voluntary schemes to substantiate marketing claims .... Some scholars have questioned the competence and accountability of third-party certifiers in voluntary certification schemes.").

175 See SEC PRAC. SECTION, supra note 125, \$5000.32; Larry Catá Backer, Surveillance and Control: Privatizing and Nationalizing Corporate Monitoring After Sarbanes-Oxley, 2004 MiCH. ST. L. Rev. 327, 401 (2004); Sarbanes-Oxley Act of $2002 \$ 102(\mathrm{e}), 15$ U.S.C. $\$ 7212(\mathrm{e})$.

176 See Bill Gradison \& Ron Boster, The PCAOB's First Seven Years: A Retrospection, 4 CurRENT IsSuEs IN AudiTing A9, A11 (2010) ("Contrary to common opinion, the bar for firms to be registered is not high. Registering a firm is not an indication in itself that the firm performs or is capable of performing quality audits.").

177 PCAOB, 2019 ANNUAL REPORT, at iii (2020), https://pcaobus.org/about/annual-report (follow hyperlink labeled “2019”).

178 PCAOB, FAQ, supra note 159, at 4 (explaining that registration alone does not subject a firm to Board oversight, and the Board's regulatory processes will not be applied to firms that are not engaged in audits covered by its regulatory authority).

179 Jeanette M. Franzel, Bd. Member, PCAOB, Address at the Association of Government Accountants 62d Annual PDC: Accountability: Protecting Investors, the Public Interest and Prosperity (July 17, 2013). 
about the import of PCAOB registration for such firms. A few years later, the Board made some effort in this regard by updating its guidance on registration to provide improved disclosure on this question. ${ }^{180} \mathrm{~A}$ significant question remains as to whether investors and public companies seeking registered auditors are aware of the limitations of the PCAOB's verifiability process.

Like the SECPS membership rules, S-Ox mandates the public availability of information submitted by applicant firms. ${ }^{181}$ Unlike SECPS rules, S-Ox qualifies the publication of firm information by directing the PCAOB to shield from public disclosure information the agency deems to be "proprietary." 182 The PCAOB executes this edict by permitting firms to identify, in registration applications and annual reports, those specific items of information the firms believes is proprietary and provide the Board with support for its assertion. ${ }^{183}$ Such information, when identified by the firm as proprietary, is shielded from public view while the firm's request that such information be treated as confidential is evaluated. ${ }^{184}$ Responsibility for making these determinations is delegated to Board staff; ${ }^{185}$ the Board may call any such determination for review, and a firm that is denied confidential treatment of alleged proprietary information may appeal that determination to the Board as well. ${ }^{186}$ Once a final determination is reached with respect to confidential treatment of the identified information, the information is disclosed to the extent permitted by the determination. ${ }^{187}$

Requests for confidential treatment of information contained in registration applications have petered out over time. Of the 740 registration applications approved between 2003 and 2005 and publicly available on the PCAOB's website, 271 contained requests for confidential treatment of information contained therein. ${ }^{188}$ Publicly available information further reveals that of the 113 registration applications approved by the Board between 2017 and 2019, none contained requests for confidential treatment. In fact, applications received during this time contained a remarkably minimal amount of information. These applications generally disclosed the firm's name, contact information, licensing information, and a summary of the firm's quality control policies. The evolution towards a virtually

180 PCAOB, FAQ, supra note 159, at 4-5.

181 See SEC PRAC. SECTION, supra note 125, $\$$ 5000.32; Backer, supra note 175, at 401; Sarbanes-Oxley Act of $2002 \$ 102(\mathrm{e}), 15$ U.S.C. $\$ 7212(\mathrm{e})$.

182 Sarbanes-Oxley Act of $2002 \$ 102(\mathrm{e}), 15$ U.S.C. $\$ 7212(\mathrm{e})$.

183 Section 2. Registration and Reporting, supra note 157, at Rule 2300. PCAOB Rule 2300 (Aug. 2009), https://pcaobus.org/about/rules-rulemaking/rules/section_2.

184 Id. at Rule $2300(\mathrm{~d})$.

185 Id. at Rule 2300(h).

186 Sarbanes-Oxley Act of $2002 \$ 101(\mathrm{~g})(2), 15$ U.S.C. $\$ 7211(\mathrm{~g})(2)$.

187 Section 2. Registration and Reporting, supra note 157, at Rule 2300.

188 Registrations may be accessed by visiting Registration, Annual and Special Reporting, PCAOB, https://rasr.pcaobus.org/Search/Search.aspx (last visited Dec. 27, 2021). 
empty registration application was inevitable under the current verifiability model of the PCAOB, as much of the information contained in the registration application relates to the firm's practice with respect to audits that are the subject of Board oversight, and the overwhelming population of applicant firms are not engaged in such activities at the time of registration. ${ }^{189}$

\section{REDESIGNING THE APPROACH TO REGULATED AUDITORS TO PRODUCE EFFECTIVE OVERSIGHT}

\section{A. Mandate Sunlight}

The PCAOB's registration process was outlined in broad strokes in the Sarbanes-Oxley Act of 2002, leaving details relating to the form, content, and process of registration to be determined by rules promulgated by the agency. ${ }^{190}$ In 2003, the Board adopted a "registration system" consisting of rules and a format for the registration application, ${ }^{191}$ with little concrete information on the criteria for registration. After more than 15 years of registering accounting firms, the registration process has remained largely unchanged, with only a few pro forma alterations in 2013 to accommodate the Dodd-Frank Act and the addition of broker-dealer audits to the Board's oversight scope. ${ }^{192}$ Yet, the demographics of the firms seeking $\mathrm{PCAOB}$ registration have changed significantly with the passage of time. ${ }^{193}$

The firms more recently seeking registration with the PCAOB generally fall into one of two categories: (1) firms that were previously registered with the Board, withdrew, and seek to register anew; and (2) firms that were not previously registered, yet seek PCAOB authorization to audit public companies and/or brokerdealers. Firms in the former category inspire a host of logical inquiries that the registration application does not address. Such inquiries include whether the firm

189 Information available on the PCAOB's website regarding registration applications indicates that of the 948 applications approved between 2003 and 2005 (and still publicly available as of December 31, 2020), 561 of those firms audited public companies in the recent past or expect to do so during the year of registration. Id. Of the 113 applications approved and available for the period of 2017 to 2019, only eight firms indicated that they expected to audit a public company during the year of registration. $I d$.

190 See generally Sarbanes-Oxley Act of $2002 \$ 102$ (codified as amended at 15 U.S.C. $\$ 7212)$.

191 See Registration System for Public Accounting Firms, PCAOB Release No. 2003-007 (May 6, 2003).

192 See Amendments to Conform the Board's Rules and Forms to the Dodd-Frank Act and Make Certain Updates and Clarifications, PCAOB Release No. 2013-010, at 5 (Dec. 4, 2013) ("[T]he Board is amending its registration, withdrawal, and reporting forms . . . and the general instructions to these forms, to call for relevant broker and dealer audit client information.”).

$193 \mathrm{Id}$. at $55 \mathrm{n} .188$ (explaining where registration application information may be found). 
audited public companies while previously registered and whether those audits were inspected by the Board. The Board's guidance on registration implies that the Board asks such questions behind its closed doors while vetting registration applications, ${ }^{194}$ but there is no transparency around that process. Firms in the latter category raise questions about the competencies of new entrants to the arena of auditing public companies. What training or experience do its personnel possess in this regard? ${ }^{195}$

The PCAOB took steps towards improving transparency in this regard when it adopted Form AP in 2016. ${ }^{196}$ Form AP requires registered firms to file reports with the PCAOB disclosing the name of the partner leading the firm's audit for each public company for which the firm serves as outside auditor. ${ }^{197}$ However, this information is not mandated on the registration application, creating a gap in the information provided to investors, scholars, and other users of the publicly available registration application. Effective regulation demands transparency and accountability around such verification processes. ${ }^{198}$

Finally, any regulatory process involving verifiability should be subject to routine and public review. The SEC's Division of Examinations (formerly the Office of Compliance, Inspections, and Examinations) is responsible for conducting examinations of the $\mathrm{PCAOB},{ }^{199}$ yet there is little evidence of such oversight on the

194 PCAOB, FAQ, supra note 159, at 6 ("In the case of registration applications of firms that have previously been registered with the Board ... the Board will also consider any relevant information learned by the Board in the course of its oversight activity.").

195 The SECPS's membership process addressed concerns about the competence of member firms engaged in accounting and auditing by, among other things, requiring its members who spend at least $25 \%$ of their time performing certain audit-related activities to devote at least $40 \%$ of their continuing education to subjects relating to accounting and auditing. See U.S. Gov'T ACCT. OfF., supra note 66, at 90. The PCAOB adopted this SECPS provision as an interim standard when it began operations in 2003, but the provision only applies to firms that were members of the SECPS at the time the interim standards were adopted. See Hearing on Accounting and Auditing Standards: Pending Proposals and Emerging Issues Before the H. Subcomm. on Cap. Mkts., Ins. and Gov't Sponsored Enters., 111th Cong. App A at 7 (2010) (statement of Daniel L. Goelzer, Acting Chairman, $\mathrm{PCAOB}$ ). To date, the $\mathrm{PCAOB}$ has not acted to finalize these standards. See J. Robert Brown Jr., Bd. Member, PCAOB, Statement Regarding the PCAOB's Revised Research and Standard-Setting Agendas: Reducing Credibility, Accountability and Confidence in the Financial Reporting Process (Oct. 13, 2020) (asserting that the Board's failure to update the interim standards adopted in 2003 was inconsistent with its promise of innovative oversight).

196 Honigsberg, supra note 105, at 1884.

197 Id.

198 See Brown, supra note 120, at 136 (advocating that non-governmental agencies with governmental powers should be subject to mechanisms, including sunshine laws, to ensure their accountability).

199 Sarbanes-Oxley Act of $2002 \$ 107$ (a), 15 U.S.C. $\$ 7217$ (a); see also Cheryl Nichols, Addressing Inept SEC Enforcement Efforts: Lessons from Madoff, the Hedge Fund Industry, and Title IV of the Dodd-Frank Act for U.S. and Global Financial Systems, 31 NW J. INT'L L. \& BUS. 637, 
SEC's website. Moreover, the SEC reportedly outsourced its monitoring function regarding the PCAOB by hiring former SEC Chairman Harvey Pitt to consult on whistleblower complaints lodged with the SEC in 2019. ${ }^{200}$ Any formula for the creation of an effective audit regulator should include independent reviews performed by a disinterested agency, such as the U.S. Government General Accountability Office.

\section{B. Streamline Verifiability}

Effective auditor regulation demands appropriate verifiability. In mandating that all firms opining on the financial statements of public companies be registered with the PCAOB, Congress relieved the Board of the SECPS's burden of coaxing firms into oversight with incentives and less onerous obligations. The PCAOB nonetheless continued the open admission practices of the SECPS with little rationale as to how the practice aligns with its regulatory mission of improved audit quality. As a result, the $\mathrm{PCAOB}$ is managing a significant population of registered firms for which it exercises no oversight. ${ }^{201}$ This practice continues to benefit firms by giving them the credential of $\mathrm{PCAOB}$ registration, but harms investors and public companies who may be unaware that registration is not an indication of the firm's audit quality. ${ }^{202}$

Registration applications from firms that do not intend to participate in audits of public companies or broker dealers are virtually devoid of information, since much of the application calls for information about audit activity. Yet these applications must be processed, reviewed, acted upon by the PCAOB, and also made publicly available. The costs of these reviews are theoretically shared among accounting firms. ${ }^{203}$ However, the registration and annual fee amounts have remained unchanged since 2010. ${ }^{204}$ The Board indicated in 2010 that it would

663 n.147 (2011).

200 Jean Eaglesham and Dave Michaels, Accounting Regulator Had Climate of Fear and Distrust, Report Says, Wall ST. J. (June 28, 2021, 6:41 PM), https://www.wsj.com/ articles/accounting-regulator-had-climate-of-fear-and-distrust-report-says-11624918488.

201 As of March 20, 2021, 866 firms registered with the PCAOB filed annual reports with the Board indicating that no activity with respect to audit reports on public companies or brokerdealers. Registered Firms, PCAOB, https://pcaobus.org/oversight/registration/registered-firms (last visited Dec. 27, 2021).

202 Adrienne Gonzalez, Per the PCAOB, Being Registered with the PCAOB Isn't the Same as Being Scrutinized by the PCAOB, GOING CONCERN (Mar. 17, 2014), https://www. goingconcern.com/pcaob-being-registered-pcaob-isnt-same-being-scrutinized-pcaob/.

203 The Sarbanes-Oxley Act provides that the Board must collect a fee from each registered public accounting firm sufficient to cover the costs of processing and reviewing registration applications and annual reports. Sarbanes-Oxley Act of $2002 \$ 102(\mathrm{f}), 15$ U.S.C. $\$ 7212(\mathrm{f})$.

204 See Announcement of Annual Fee and Increase in Minimum Registration Application Fee, PCAOB Release No. 2010-002 (April 13, 2010) (announcing an increase in the registration 
adjust the annual fee as necessary to "take account of variances between estimated costs and actual costs, or significant changes in the number of registered firms," ${ }^{205}$ but has publicly disclosed no such adjustments since that date. In the absence of public information about the costs of these processes, it is unclear whether the fees being collected are adequate, or whether those costs are being underwritten by SEC registrants, and therefore public investors. ${ }^{206}$

\section{Strengthen Registration Criteria}

A redesigned approach to audit regulation should provide tangible criteria for verifiability. Firms seeking to audit public companies should demonstrate some minimal knowledge of these specialized audits, either by experience or by specialized training. It is overly optimistic to expect a firm that has never audited a public company to perform such an audit skillfully, and somewhat mystifying for a public company to select such a firm as its outside auditor. Research performed by a team of scholars, including a PCAOB Economic Research Fellow, used proprietary PCAOB data to conclude that first-time auditors of public companies perform lower quality audits, are more likely to be cited for audit deficiencies by $\mathrm{PCAOB}$ inspectors in their initial and subsequent audits, are more likely to be the subject of PCAOB enforcement actions, and spend less time performing audits. ${ }^{207}$

This concept is further exemplified in the disciplinary action brought by the PCAOB against the registered firm of HLB Mann Judd ("HLB") in $2020 .{ }^{208}$ HLB, located in Australia, registered with the PCAOB in February 2015. ${ }^{209}$ Its registration application disclosed the firm's plan to audit an issuer, CBD Energy Limited, during 2015. ${ }^{210}$ The application included the firm's contact information, licensing

fee set in 2003 for firms with no issuer clients and setting the annual fee for registered firms).

205 See id. at 2.

206 Kenneth B. Orenbach, A New Twist to an On-Going Debate About Securities SelfRegulation: It's Time to End FINRA's Federal Income Tax Exemption, 31 VA. TAX REV. 135, 193 n.300 (2011) (explaining that while audit firms pay fees to the PCAOB, the vast majority of its annual revenues are derived from fees levied upon public companies in proportion to their average market capitalizations and upon certain broker-dealers).

207 Andrew Kitto, Phillip T. Lamoreaux \& Devin Williams, Do Entry Barriers to the Public Company Audit Market Deter Low Quality Audit Firms?, (May 6, 2020) (unpublished manuscript), https://papers.ssrn.com/sol3/papers.cfm?abstract_id=3572688. The paper noted, "These findings are consistent with first time auditors providing a misleading signal of quality prior to entering the market." Id. This author posits that the PCAOB's approval of these firms' registration applications could be one of those signals.

208 See HLB Mann Judd, Darryl Swindells \& Aidan Smith, Order Instituting Disciplinary Proceedings, Making Findings, and Imposing Sanctions, PCAOB Release No. 105-2020-008 (June 29, 2020).

209 Id. at 2-3.

210 HLB Mann Judd: Application for Registration with PCAOB, PCAOB 8 (Jan. 27, 2015), 
information regarding the firm and its personnel, and the firm's quality control manual. The application, in accordance with Board rules, contained no information about the firm's experience or training in auditing U.S. public companies. ${ }^{211}$

BlueNRGY Group Limited, successor to CBD Energy Limited, filed an amended annual report with the SEC (on Form 20-F) in July 2015, indicating that its auditor, PricewaterhouseCoopers, had resigned in November 2014 because the outstanding and unpaid professional fees owed by the company deprived the auditor of its ability to be independent. ${ }^{212}$ The annual report also disclosed that BlueNRGY had been in a voluntary program regarding its insolvency, and further, that its audited financial statements for fiscal years 2013 and 2012 could no longer be relied upon. $^{213}$ The company indicated that it had appointed HLB to reaudit the company's financial statements for 2012 and 2013, as well as audit its financial statements for 2014..$^{214}$

After its registration with the PCAOB was approved, HLB issued audit reports on the company for its fiscal years 2012 through $2014 .{ }^{215}$ HLB then issued audit reports on the company for fiscal years 2015 through 2017.216 The PCAOB inspected audits of the firm in 2018 and released its findings of audit deficiencies in 2019..$^{217}$ In June 2020, the Board revoked the registration of the firm based on numerous violations of $\mathrm{PCAOB}$ rules, including its failure to consider whether it was competent to undertake the engagement and whether Australian audit standards were different from those mandated by the PCAOB. ${ }^{218}$

HLB Mann is the poster child for a rethink on the standard applied by an audit regulator for the registration of accounting firms seeking to audit public companies. The regulator for public company auditors should set minimum criteria for verifiability, including experience and education. Requiring that firms seeking to audit public companies have some tangible indicia of knowledge apropos to the task would reflect a true shift from an industry-centered organization interested in facilitating access to public companies for firms of any caliber, to a regulation-

https://rasr.pcaobus.org/Forms/FormSummary.aspx?ID=E55FF5689BBC613C7E56F57E0412F109.

211 See id.

212 See BlueNRGY Grp. Ltd., Annual Report (Form 20-F/A), at 31 (July 10, 2015 ).

213 See id. at 32, 74.

214 See id. at 31.

215 HLB Mann Judd, Darryl Swindells \& Aidan Smith, Order Instituting Disciplinary Proceedings, Making Findings, and Imposing Sanctions, PCAOB Release No. 105-2020-008, at 3 (June 29, 2020).

216 Id. at 3-4.

217 See Report on 2018 Inspection of HLB Mann Judd, PCAOB Release No. 104-2019075, at 3 (Feb. 28, 2019).

218 HLB Mann Judd, Darryl Swindells \& Aidan Smith, Order Instituting Disciplinary Proceedings, Making Findings, and Imposing Sanctions, PCAOB Release No. 105-2020-008, at 1 (June 29, 2020). 
focused agency that is truly concerned about the quality of audits being performed. Such criteria could deprive smaller firms of any perceived prestige associated with grants of registration, but creates little concern from a regulatory perspective that is centered on improved audit quality.

A former PCAOB Board member gave a speech in 2018 suggesting that the Board might delve more deeply into a firm's quality control processes during the application process, rather than just examine the quality control policies the firm provides with the application. Former Board Member Hamm remarked:

If we get more information on the design and implementation of an applicant's quality control protocols upfront, we are better able to spot patent defects and weaknesses. Armed with that information, we could require the applicant to fix those shortcomings before ever auditing the financial statements of a public company or broker-dealer. In other words, putting prevention into action. ${ }^{219}$

This sentiment well reflects the potential of the registration process as a regulatory tool to improve the quality of audits in advance of potentially subpar audit reports that are relied upon by investors.

\section{CONCLUSION}

Regulation itself is challenging, representing a perpetual tension between the desire to rectify abuses and the need to deliver benefits to regulated entities. ${ }^{220}$ That tension could easily explain the decades-old failure to unlock the alchemy of effective audit regulation, but provides no administrable formula to achieve the desired output of tangible and measurable improvement in audit quality. Whether the PCAOB is subsumed under the SEC, is replaced by yet another new regulatory creation, or continues its current existence, verifiability is a key component of regulation that must be addressed. This Article concludes that effective regulation of auditors must be permeated with the goal of high audit quality. That theme must be incorporated into the criteria used to determine which accounting firms should be authorized to audit public companies, and the disclosures that such firms must provide in seeking authorization. Firms seeking permission to audit publicly held companies should be required to demonstrate adequate training and knowledge for doing so. The personnel involved in these audits should be required to disclose their

219 Kathleen M. Hamm, Bd. Member, PCAOB, Quality Control: The Next Frontier at the University of Tennessee Neel Corporate Governance Distinguished Speaker Series (Nov. 30, 2018).

220 See Jack High, Introduction: A Tale of Two Disciplines, in Regulation: Economic THEORY AND HisTORY 1, 1-6 (Jack High ed., 1991) (describing the shift in economic theory from identifying the motivation for regulation as the advancement of public interests to the advancement of regulated business's interests). 
involvement at each stage of interaction with the regulator, including at registration. The notion that all accounting firms not otherwise barred should be permitted to audit public companies for the sake of competition must be soundly rejected. Finally, the regulator should be obligated to perform regular self-assessment of its verifiability processes and should be subjected to credible, routine, and independent examinations of its performance. 
APPENDIX 1: CONTENT OF SECPS AND PCAOB APPLICATIONS

\begin{tabular}{|c|c|c|c|c|}
\hline $\begin{array}{c}\text { Application } \\
\text { Content by Topic }\end{array}$ & $\begin{array}{c}\text { SECPS } \\
\text { (as of Aug. } \\
1979 \text { ) } \\
\end{array}$ & $\begin{array}{c}\text { SECPS } \\
\text { (as of June } \\
1997 \text { ) } \\
\end{array}$ & $\begin{array}{l}\text { PCAOB } \\
\text { (as of Aug. } \\
\text { 2003) }\end{array}$ & $\begin{array}{c}\text { PCAOB } \\
\text { (as of Dec. } \\
\text { 2013) }\end{array}$ \\
\hline $\begin{array}{l}\text { Agreement to } \\
\text { cooperate with requests } \\
\text { for testimony or } \\
\text { documents }\end{array}$ & $\mathrm{X}$ & $\mathrm{X}$ & $\checkmark *$ & $\checkmark *$ \\
\hline $\begin{array}{l}\text { Agreement to Comply } \\
\text { with Organization } \\
\text { Obligations }\end{array}$ & $\checkmark$ & $\checkmark$ & $\mathrm{X}$ & $\mathrm{X}$ \\
\hline $\begin{array}{l}\text { Name of Contact } \\
\text { Person }\end{array}$ & $\mathrm{X}$ & $\checkmark$ & $\checkmark$ & $\checkmark$ \\
\hline $\begin{array}{l}\text { Legal Form of } \\
\text { Organization } \\
\text { (partnership, etc.) }\end{array}$ & $\checkmark$ & $\checkmark$ & $\checkmark$ & $\checkmark$ \\
\hline $\begin{array}{l}\text { Firm licenses } \\
\text { authorizing auditing or } \\
\text { accounting }\end{array}$ & $\mathrm{X}$ & $\mathrm{x}$ & $\checkmark *$ & $\checkmark$ \\
\hline Organization Chart & $\checkmark$ & $\mathrm{x}$ & $\mathrm{x}$ & $\mathrm{x}$ \\
\hline $\begin{array}{l}\text { Firm's year ends (for } \\
\text { both fiscal and } \\
\text { continuing education } \\
\text { purposes) }\end{array}$ & $\mathrm{X}$ & $\checkmark$ & $\mathrm{X}$ & $\mathrm{X}$ \\
\hline Firm Offices & $\checkmark$ & $\checkmark$ & $\checkmark$ & $\checkmark$ \\
\hline $\begin{array}{l}\text { Count of CPAs, } \\
\text { professional staff and } \\
\text { total personnel }\end{array}$ & $\checkmark$ & $\checkmark$ & $\checkmark$ & $\checkmark$ \\
\hline $\begin{array}{l}\text { Names of SEC Audit } \\
\text { Clients }\end{array}$ & $\checkmark$ & $\mathrm{X}$ & $\checkmark *$ & $v^{*}$ \\
\hline $\begin{array}{l}\text { Statement that Firm } \\
\text { has complied with } \\
\text { applicable } \\
\text { independence } \\
\text { requirements }\end{array}$ & $\checkmark$ & $\checkmark$ & $\mathrm{X}$ & $\mathrm{X}$ \\
\hline $\begin{array}{l}\text { Description of firm's } \\
\text { quality control } \\
\text { policies, including } \\
\text { those to monitor } \\
\text { independence }\end{array}$ & $\mathrm{X}$ & $\mathrm{X}$ & $v^{*}$ & $v^{*}$ \\
\hline $\begin{array}{l}\text { Information required } \\
\text { under GAAP regarding } \\
\text { pending litigation }\end{array}$ & $\checkmark$ & $\checkmark$ & $\mathrm{x}$ & $\mathrm{x}$ \\
\hline $\begin{array}{l}\text { Information regarding } \\
\text { specified criminal, } \\
\text { governmental, civil, } \\
\text { administrative or } \\
\text { disciplinary } \\
\text { proceedings }\end{array}$ & $\mathrm{X}$ & $\mathrm{X}$ & $v^{*}$ & $v^{*}$ \\
\hline
\end{tabular}




\begin{tabular}{|c|c|c|c|c|}
\hline $\begin{array}{l}\text { Information regarding } \\
\text { fees charged to SEC } \\
\text { audit clients for various } \\
\text { audit and non-audit } \\
\text { services }\end{array}$ & $\checkmark$ & $\checkmark$ & $\checkmark *$ & $\checkmark^{*}$ \\
\hline $\begin{array}{l}\text { Information Regarding } \\
\text { Disagreements with } \\
\text { Former SEC Audit } \\
\text { Clients }\end{array}$ & $\mathrm{X}$ & $X$ & $\checkmark^{*}$ & $\checkmark *$ \\
\hline $\begin{array}{l}\text { Confirmation that } \\
\text { Firm reported pending } \\
\text { litigation to } \\
\text { appropriate AICPA } \\
\text { Committee }\end{array}$ & $\mathrm{X}$ & $\checkmark$ & $\mathrm{X}^{* *}$ & $\mathrm{X}^{* *}$ \\
\hline $\begin{array}{l}\text { Information on } \\
\text { mergers/acquisitions } \\
\text { with other Firms }\end{array}$ & $\mathrm{X}$ & $\checkmark$ & $\mathrm{X}^{* *}$ & $\mathrm{X}^{* *}$ \\
\hline $\begin{array}{l}\text { Name and location of } \\
\text { foreign associated firms } \\
\text { in shared professional } \\
\text { network with Firm }\end{array}$ & $\mathrm{X}$ & $\checkmark$ & $\mathrm{X}^{* *}$ & $\mathrm{X}^{* *}$ \\
\hline $\begin{array}{l}\text { Name and location of } \\
\text { associated entities } \\
\text { engaged in accounting } \\
\text { or issuing audit reports }\end{array}$ & $\mathrm{X}$ & $\mathrm{X}$ & $\checkmark$ & $\checkmark$ \\
\hline $\begin{array}{l}\text { List of accountants } \\
\text { associated with Firm } \\
\text { and corresponding } \\
\text { license numbers }\end{array}$ & $\mathrm{X}$ & $\mathrm{X}$ & $\checkmark *$ & $\checkmark *$ \\
\hline
\end{tabular}

* Mandated by Sarbanes-Oxley Act of 2002

** Reporting of item is required after resignation 